\section{Computational modelling of Yorùbá numerals in a number-to-text conversion system}

\author{
Olúgbénga O. Akinadé and Odẹttúnjí A. Odẹjọbí \\ Computing and Intelligent Systems Research Group \\ Department of Computer Science and Engineering \\ Ọbáfẹ́mi Awólọ́wọ̀ University \\ Ilé-Ifẹ̀, Nigeria
}

\begin{abstract}
ABSTRAGT
In this paper, we examine the processes underlying the Yorùbá numeral system and describe a computational system that is capable of converting cardinal numbers to their equivalent Standard Yorùbá number names. First, we studied the mathematical and linguistic basis of the Yorùbá numeral system so as to formalise its arithmetic and syntactic procedures. Next, the process involved in formulating a ContextFree Grammar (CFG) to capture the structure of the Yorùbá numeral system was highlighted. Thereafter, the model was reduced into a set of computer programs to implement the numerical to lexical conversion process. System evaluation was done by ranking the output from the software and comparing the output with the representations given by a group of Yorùbá native speakers. The result showed that the system gave correct representation for numbers and produced a recall of $100 \%$ with respect to the collected corpus. Our future study is focused on developing a text normalisation system that will produce number names for other numerical expressions such as ordinal numbers, date, time, money, ratio, etc. in Yorùbá text.
\end{abstract}

Keywords:

Analysis of numerals, Yorùbá numerals, numbers to text, text normalisation 


\section{INTRODUGTION}

The use of numbers and their power in capturing concepts makes them indispensable in effective communication (Goyvaerts 1980). In any society, the use of numbers is firmly anchored to numerous beliefs and perceived usefulness of the significant philosophy underlying numerical messages (Abímbọ́lá 1977). In fact, key advancement in civilisation can be traced to the conception, invention, representation, and manipulation of numbers to facilitate accurate rendering of measurable objects. This has made the use of numbers an important tool within the society, where it is used in trade, cosmology, mathematics, divination, music, medicine, etc. Early cultures devised various means of number representation, which include body/finger counting (Zaslavsky 1973; Saxe 1981), object counting, Egyptian numerals, Babylonian numerals, Greek numerals, Chinese numerals, Roman numerals, Mayan numerals, Hindu-Arabic numerals, etc. The Hindu-Arabic numeral system, which is considered to be the greatest mathematical discovery (Bailey and Borwein 2011), is still the most commonly used symbolic representation of numbers due to its simplicity and the fact that it requires little memorisation to represent practically any number.

Naming numbers in human languages requires various mathematical and linguistic processes. For example, the number 74 is represented as $70(7 \times 10)$ increased by 4 in English, whereas it is represented as $60(6 \times 10)$ increased by $14(4+10)$ in French. In Logo, the number 74 is represented as 10 added to $60(20 \times 3)$ increased by 4 . In Yorùbá, in turn, the same number is derived in a more complex way by adding 4 to $80(20 \times 4)$ reduced by 10 . Table 1 shows the representation of the number 74 in the four languages.

The analysis of number names is important but understudied in human language processing. While it may seem trivial to compute number names in languages like English, it may be difficult to get it

\begin{tabular}{|c|c|c|c|}
\hline \multirow{5}{*}{$\begin{array}{r}\text { Table 1: } \\
\text { Derivation of } \\
\text { the number } 74 \\
\text { in four languages }\end{array}$} & Language & Name & Derivation \\
\hline & English & seventy four & $(7 \times 10)+4$ \\
\hline & French & soixante-quatorze & $60+14$ \\
\hline & Logo & nyab̂a na drya mudri drya su & $(20 \times 3)+10+4$ \\
\hline & Yorùbá & ẹ̀rìnléláàdọrin & $4+(-10+(20 \times 4))$ \\
\hline
\end{tabular}


right in many other languages, particularly in the Yorùbá language. In this paper, we present a formal description of the Yorùbá numeral system; specifically, the problem of Yorùbá number name transcription is addressed from an engineering perspective, by applying standard theories and techniques to an understudied language. This is part of a wider interest in the development of Text-To-Speech (TTS) synthesis and Machine Translation (MT) systems for the Yorùbá language. In TTS and related applications, text normalisation is often the first task, in which Non-Standard Words (NSW) such as numbers, abbreviations, acronyms, time, date, etc. are correctly identified and expanded into their textual forms (Sproat 1996). The expansion of numerical expressions in text is thus a key task in such applications because numbers occur more frequently in varying forms within a block of text. These forms include cardinal numbers, ordinal numbers, telephone numbers, date, time, percentages, monetary value, address, etc.

The rest of this paper is structured as follows: Section 2 gives an analysis of the Yorùbá numeral system and its associated number naming rules. Section 3 discusses the system design and implementation, while Section 4 discusses the results. Section 5 presents the system evaluation and Section 6 concludes the paper with areas of further study.

\section{THE YORÙBÁ NUMERALS}

The Yorùbá language (ISO 639.3 yor), which belongs to the West Benue-Congo branch of the Niger-Congo African languages family, is spoken by about 19,000,000 speakers in the South-Western Nigeria (Owolabi 2006). The language is also spoken in other West African countries such as Central Togo, the East-Central part of the Republic of Benin, and Creole population of Sierra Leone. Outside Africa, Yorùbá (called Nagô, Aku, or Lukumi; Lovejoy and Trotman 2003) is spoken in Brazil, Cuba, and Trinidad and Tobago.

Without a formal method of documenting literature, the Yorùbá community developed a complex numeral system that extensively uses subtraction throughout its system (Verran 2001). This has attracted many linguistic scholars to investigate the reasons why this community has developed an intricate numeral system. Certainly, knowledge of the Yorùbá numeral system has been passed from generation to 
generation by means of oral literature. Young language learners, in particular, are made to undergo drills of reciting rhymes with numbers ranging from 1 to 10 .

In an early study of the Yorùbá numeral system, Mann (1887) shows how large numbers could be represented as an arithmetic combination of the basic number units and reveals that the subtraction operation plays an important role in number naming. The peculiarity in the Yorùbá numerals was highlighted as follows:

"Very different is the framework of the Yorùbá, it can boast of a greater number of radical names of numerals, and to a large extent makes use of subtraction..." (Mann 1887, p. 60)

A fact worth noting is that some systems illustrate a pervasive use of the subtractive techniques. Examples of such systems are the clock system and the Roman numeral system. In the conventional clock system, when the minute part of time is greater than 30 minutes, the spoken representation can be derived by employing the subtractive technique. For instance, four canonical representations of 2:30 PM are:

(i) Half two (half hour past two)

(ii) Two thirty (2 o'clock $+30 \mathrm{~min}$ )

(iii) Thirty minutes after two (2 o'clock $+30 \mathrm{~min}$ )

(iv) Thirty minutes to three (3 o'clock $-30 \mathrm{~min}$ )

All four representations in (i) to (iv) are acceptable and none has precedence over the other. The form in (iv) is used to a large extent in our daily lives without any difficulty. Similarly, halb zwei in German means 'half of the second hour', which is 'half one'. So, the Yorùbá's use of subtraction is not completely exceptional, but its extensive usage may seem unusual, especially when it is preferred over the simpler addition operation.

Another observable feature of the Yorùbá numeral system is the use of base 20 (vigesimal), which likely stems from the counting of cowry shells as described by Mann:

"Here we may explain the origin of this somewhat cumbersome system; it springs from the way in which the large sum of money (cowries) are counted. When a bagful is cast on the floor, the 
counting person sits or kneels down beside it, takes 5 and 5 cowries and counts silently, 1, 2, up to 20, thus 100 are counted off, this is repeated to get a second 100, these little heaps each of 100 cowries are united, and a next 200 is, when counted, swept together with the first" (Mann 1887, p. 63)

However, there are vigesimal systems that do not have any relation to cowry shells. A more obvious reason for vigesimal systems could be that humans have 10 fingers and 10 toes. The use of 20 as a base may seem cumbersome, however, it is not entirely exceptional. In many languages, especially in Europe and Africa, 20 is a base with respect to the linguistic structure of the names of certain numbers. Even so, a consistent vigesimal system based on the powers of 20, i.e.: 20, 400,8000 , etc. is not generally used. Examples of a strict vigesimal numeral system are those of Maya and Dzongkha (the national language of Bhutan). The numeral systems of the Ainu language of Japan and Kaire language of Sudan also rely, to an extent, on base 20 for the representation of numbers. Apart from Yorùbá, other African languages with vigesimal numeral system are: Madingo, Mundo, Logone, Nupe, Mende, Bongo, Efik, Vei, Igbo, and Affadeh (Conant 1896). The study by Conant (1896) highlighted the extent of the mental computation required in the expression and conception of the Yorùbá numerals, and concluded that the Yorùbá numeral system is the most peculiar numeral system in existence. One might then begin to wonder why the Yorùbá language, with a simple syllabic structure, will use such a complex numeral system. The reason for this may not be too clear.

Johnson (1921) conducted an analysis of the Yorùbá numerals by focusing on the derivation processes and the morphophonological rules required, and showed how large numbers are calculated in multiples of 20,000. The study by Abraham (1958) examined the arithmetic skills employed in different Yorùbá numeral groups, and provided a guide into their syntactic representation. A profound study on Yorùbá numerals was done by Ekkúndayọ (1977), where the derivational breakdown of the Yorùbá numerals was discussed and the structural representation of Yorùbá numerals was illustrated. In the study, 16 basic number lexemes which serve as the basic building blocks of the Yorùbá numeral system were identified as presented in Section 2.1. 
The Yorùbá counting system has lexemes for basic numbers from 1 to 10 and six higher numerals (i.e.: 20, 30, 200, 300, 400, and 20,000). These 16 basic number lexemes are:

ọkan (1), èjì (2), ẹta (3), ẹrrin (4), àrún-ún (5), èfà (6), èje (7), èjo (8), èsán-án (9), èwá (10), ogún (20), ogbọ̀n (30), igba (200), ọdúnrún (300), irínwó (400), ọkẹ (20,000) (Ẹkúndayọ 1977)

Abraham (1958) and Ẹkúndayọ̀ (1977) also highlighted another set of basic numerals which are multiples of 20 from 20 to 80 . These include:

okòó (20), òjì (40), ọtà (60), and ọ̀rìn (80).

These forms of lexemes are used with multiples of 100 between 200 and 20,000. The lexical representation of 20 has two values, i.e., ogún or okòó, which are used in different contexts. Okòó is the only form used in initial word positions when it is added to (ó lé) or subtracted from (ó dín) a vigesimal, while ogún is used with the multiplication formatives in numerical derivation. To illustrate this, 220 may either be expressed as igba ó lé ogún (200 increased by 20) or okòólérúgba (20 added to 200) but not as igba ó lé okòó or ogúnlérúgba although they would represent the same quantity.

Numbers are generated using syntactic combination of these lexemes, and only three of the basic mathematical operators are required to represent an infinite set of numbers within the Yorùbá language. These operators are represented by special position words like lé for addition, dín for subtraction, and ònà for multiplication. However, it should be pointed out that subtraction has an unusually higher functional load than addition. An exponential represented as ilopo may be required to express very large numerals as powers of 20,000 (Ọdẹjọbí 2003) but this is not generally used in the Yorùbá numeral system. Overcounting in Yorùbá numerals

We have mentioned the use of three of the standard arithmetic operations (i.e., multiplication, subtraction, and addition) in the Yorùbá numeral system. However, it is important to discuss a special mode of subtraction depicted by eẹiin and its variant, aadín. The eedín phenomenon was well articulated in Ẹkúndayọ (1977), where a detailed 
explanation of this concept was given. Overcounting (Menninger 1969) occurs when a numeral is expressed in relation to a higher numeral. Overcounting, thus, becomes inevitable within any numeral system employing subtraction operation in number representation.

In the Yorùbá numerals system, when eedin is used with a number, it implies that the number must be reduced by a certain value. The use of eedin or aadin is context-dependent; hence, the value deducted varies depending on the numeral to which it is attached. This is shown in Table 2. When eedin' is used with numbers 20 and 30, 5 is deducted from them to produce 15 (eẹdín ogún = ẹẹdógún) and 25 (eẹdín ogbọn = ẹ̀ẹdọgbọnn) respectively. But if eẹdín is used with 600, 100 is deducted to produce 500 (ẹdín egbẹta = ẹ̀ẹdẹgbẹta).

\begin{tabular}{lll}
\hline Variant & Number & Reduction \\
\hline ẹdín & 20 and 30 & 5 (half of 10$)$ \\
aadín & $60,80, \ldots, 200$ & 10 (half of 20$)$ \\
ẹdín & $600,800, \ldots, 2000$ & 100 (half of 200) \\
ẹedín & $4000,6000, \ldots, 20000$ & 1000 (half of 2000) \\
\hline
\end{tabular}

Table 2: 'ẹdin' mode of subtraction

The concept of overcounting is also noticeable in the numeral systems of Ainu and Maya. Danish, an essentially Germanic language, also exhibits a related subtractive phenomenon (Conant 1896) as illustrated below:

a) $50=$ halvtredsindstyve $=$ half (of 20) from $3 \times 20$

b) $70=$ halvfierdsindstyve $=$ half (of 20) from $4 \times 20$

c) $90=$ halvfemsindstyve $=$ half (of 20) from $5 \times 20$

Notably, the process of naming numbers in Danish is similar to Yorùbá. Now, we present the rules used in naming numbers in Yorùbá. Yorùbá number naming rules

There are basic rules that hold in the generation of an infinite set of number names in the Yorùbá language as captured in Figure 1. As observed by Hurford (2001), numeral sequences in human languages show several discontinuities in their patterns of representation. Therefore, it is important to identify numeral groups that exhibit similar derivative process within the Yorùbá numeral system. This is to 
Figure 1:

Knowledge for

Yorùbá numerals

generation

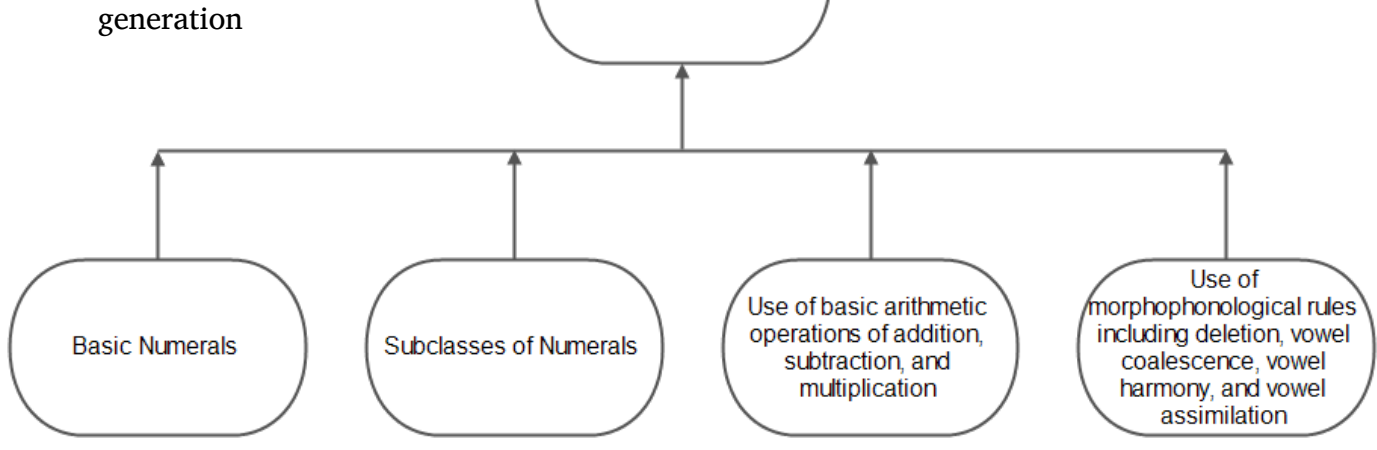

achieve the design of an effective computational model to handle the mathematical and syntactic structure of each group. The groups are:

a) Basic numbers: The canonical lexemes in the Yorùbá language have been discussed in Subsection 2.1. This set of lexemes cannot be broken down to simpler forms, and other number names are generated using arithmetic combinations of these lexemes.

b) Numbers from 11 to 200: The addition operation is used for deriving numbers from one to four above multiples of 10 , while numbers from five to one below such points are obtained through subtraction as illustrated in Figure 2. The Yorùbá lexical representation of number 11 is formed as an additive concatenation of the terms for numbers 1 and 10. This also applies to numbers 12,13 , and 14 as :
i) $11=(1+10)=$ ọkan lé ẹwá = ọkànlá
ii) $12=(2+10)=$ èjì lé è̀á $=$ èjilá
iii) $13=(3+10)=$ èta lé èwá = ètànlá
iv) $14=(4+10)=$ ẹrìn lé è̀wá $=$ ẹrìnlá

Note that the lexical representation of ' +10 ', i.e., le ẹwá is contracted to lá. The Numbers from 15 to 19 are represented as 5 to 1 deducted from 20 , respectively.
i) $15=5$ from $20=$ àrún-úndínlógún
ii) $16=4$ from $20=$ èrindínlógún
iii) $17=3$ from 20 = ètadínlógún 


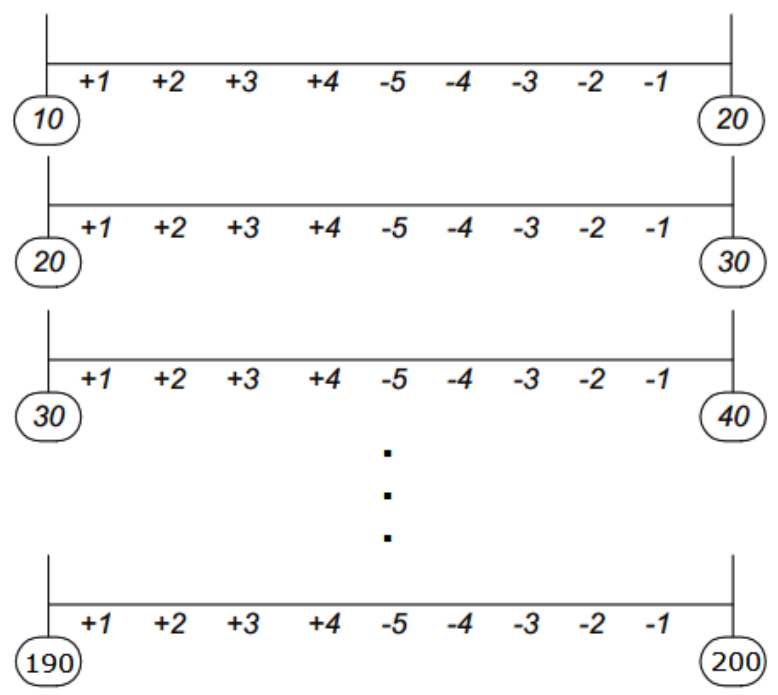

Figure 2:

Yorùbá number scale

iv) $18=2$ from $20=$ èjìdínlógún

v) $19=1$ from 20 = ọkàndínlógún

Multiples of 20 from 40 to 180 are expressed as such in successive elision and vowel harmony. Numerals 50, 70, 90, 110, 130, 150 and 170 are expressed as 10 deducted (aadín) from the next multiple of 20. Again, this is illustrated below:

i) $40=(20 \times 2)=$ ogún èjì $=$ ogójì

ii) $50=10$ less $(20 \times 3)=$ aadín (ogún ẹta) $=$ ààdọta

iii) $110=10$ less $(20 \times 6)=$ aadín (ogún èfà) = ààdọfà

iv) $180=20 \times 9=$ ogún èsàn-án = ogọsàn-án

Notably, a possible representation of 30 is ààdóji, which means 10 deducted from 2 twenties $((20 \times 2)-10)$, but 30 is referred to as ogbọn, which is a generic term in the Yorùbá numeral system.

c) Numbers From 200 to 2000: Apart from 400, numbers which are multiples of 200 are derived in multiples of igba and the numbers $500,700,900,1100,1300,1500,1700$, and 1,900 are derived by 100 deducted (eedín) from the next multiple of 200 .

i) $600=(200 \times 3)=$ igba èta $=$ egbẹta

ii) $1000=(200 \times 5)=$ igba àrùn-ún = egbèrún-ún 
iii) $1400=(200 \times 7)=$ igba èje $=$ egbèje

iv) $1500=(1600-100)=(200 \times 8)-100=$ eedín igba èjọ $=$ èẹdégbèjo

v) $2000=(200 \times 10)=$ igba ẹ̀wá $=$ egbệwá $=$ egbàá

d) Numbers Between 2,000 and 20,000: Numbers in this subgroup are formed from 2,000 as the root word. The multiples of 2,000 within this range are expressed as multiples of egbàa and intermediate numbers are formed with the eedin that shows a subtraction of 1,000 .

i) $6,000=(2,000 \times 3)=$ egbàa èta $=$ egbààta

ii) $10,000=(2,000 \times 5)=$ egbàá àrún-ún $=$ egbààrún-ún

iii) $15,000=(16,000-1000)=(2,000 \times 8)-1000=$ eedín egbàá èjọ $=$ eẹdegbààjọ

iv) $20,000=(2,000 \times 10)=$ egbàa è̀wá $=$ egbààwá. This number is also expressed as ọkẹ kan.

e) Numbers 20,000 and above: Numerals greater than 20,000 are derived as a multiple of 20,000 (ộẹ́ kan = twenty thousand in one place).

i) $40,000=(20,000 \times 2)=$ ọkẹ méjì

ii) $1,000,000=(20,000 \times 50)=$ ààdọta ọké

iii) $800,000,000=(20,000 \times 20,000 \times 2)=$ ọkẹ ona ọkẹ méjì

iv) $8,000,000,000,000=20,000 \times 20,000 \times 20,000=$ ọkẹ ọnà ọké ọnà ộẹ́ kan

Once the number groups are identified, Yorùbá numerals can be represented as a combination of members from each group using the addition and subtraction operations. For example, the number 45,678 will be represented as:

$$
45,678=40,000+5,000+600+70+8
$$

A close observation of these groups shows that certain numbers occur as reference points in the Yorùbá numeral system as proposed by Pollmann and Jansen (1996). An observable trend is that the numbers 20 and 10 play important roles within the Yorùbá numeral system. 
In this section, we review two important bibliographic references on the syntactic structure of numerals. The first one is Hurford (1975), which is an extensive study of various numeral systems. The other one is the study conducted by Ekúndayọ̀ (1977), in which phrase structure rules were proposed for the Yorùbá numeral system.

\subsection{1}

Hurford's generative numeral grammar

A notable work on the application of generative grammar to numerals is the work of Hurford (1975), where the universal phrase structure rules for deriving numerals were presented. A modified version of the phrase structure rules was presented in Hurford (2007), being a significant improvement with respect to well-formed numerals. In this extensive study of numerals, Hurford considered numerals as syntactic structural constructs and proposed a universal constraint on numerals, which he called the packing strategy. The packing strategy helps to make the right choice for a number name from different structural constructs derived by the production rules presented in Definition 1 . The packing strategy guides the general constraints on the well-formed nature of numerals and any structure containing an ill-formed structure is itself ill-formed.

\section{Definition 1 (Hurford's production rules for Yorùbá numerals)}

Hurford's production rules for the Yorùbá numeral system are as follows:

$$
\begin{aligned}
N U M & \rightarrow\left\{\begin{array}{c}
D I G I T \\
N P
\end{array}\right\}(N U M) \\
N P & \rightarrow(M) N U M \\
M & \rightarrow 10\left(\left\{\begin{array}{c}
2 \\
M
\end{array}\right\}\right)
\end{aligned}
$$

Where DIGIT is a set of basic number lexemes, $M$ is a set of multiplicative base lexemes, NUM is a numeral and the start symbol, and NP is a Number Phrase. Rule (2) is interpreted as addition/subtraction, and it can occur in reverse order, i.e., NUM $\rightarrow$ NUM NP. Rules (3) and (4) are interpreted as multiplication when two constituents are chosen. The curly brace in the production rules shows alternative productions, while parenthesis indicates 
an optional item. For example, an NP can be formed from a single NUM or a multiplicative combination of $M$ NUM.

Hurford's generative framework provides an adequate account for the numeral system of most languages including English. However, the grammar was structurally inadequate for the Yorùbá numeral system. It is worth noting that the grammar does not provide an adequate mechanism to differentiate between the addition and subtraction operations in Rule (2). For example, Hurford (1975) presented structures for 46 and 4,600, as shown in Figure 3. In the structure in Figure 3(a), 46 (ẹrindínlààdọta) was derived by deducting 4 (ẹrin) from 50 (ààdọta) and 50 was derived by deducting 10 from 60 (ògọ́ta). In Figure 3(b) and (c), representing structures for 4,600, i.e., egbẹtalélogún $(200 \times 23)$ and egbààji ó lé egbẹtta $(4,000+600)$ respectively, 23 (ẹtalélogún) was derived by adding 3 (ẹta) to 20 (ogún) and 4,600 was derived by 4,000 plus 600. Rule $N U M \rightarrow N U M N P$ is interpreted as subtraction in Figure 3(a), whereas, it is interpreted as addition in Figures 3(b) and (c). This means that the structure in Figure 3(a) could be misinterpreted as 54, and structures in Figure 3(b) and (c) as 3,400. Therefore, this introduces ambiguity in interpretation. It is also important to point out that Rule (4) results in an incorrect interpretation of the structures of $M$. To illustrate this, the rule represents 20 (ogún) as a combination of 10 (ẹwwá) and 2 (èjì), which is structurally incorrect. This is because ogún is not formed, by any means, from the combination of ẹwá and èjì.

The study also acknowledged that multiple structures may exist for some numbers like 4,600, as shown in Figures 3(b) and 3(c), but concluded that the structure in 3(c) was ill-formed, whereas it is a valid structure in Yorùbá. This conclusion could result from a limited expert knowledge in verifying the correctness of these structures, as noted:

"Despite the difficulty in finding crucial information in the sources, it is conceivable that some complete account of Yorùbá numerals can be given that is soundly motivated. This language certainly presents the weightiest challenge for a general theory of numerals that we have encountered." (Hurford 1975, p. 232) 
(a)

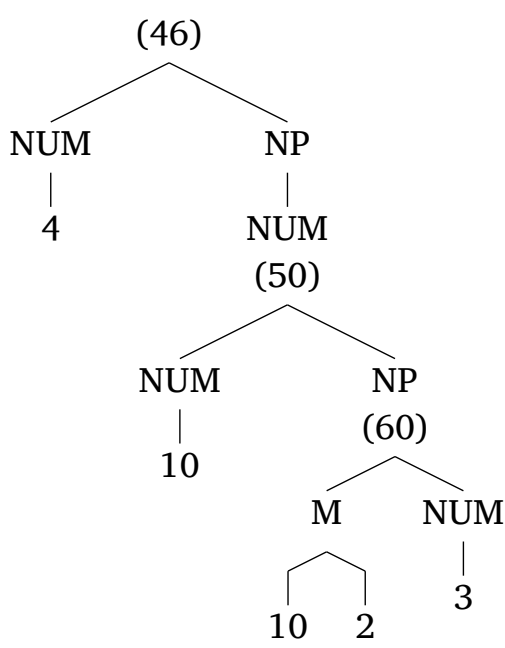

(b)

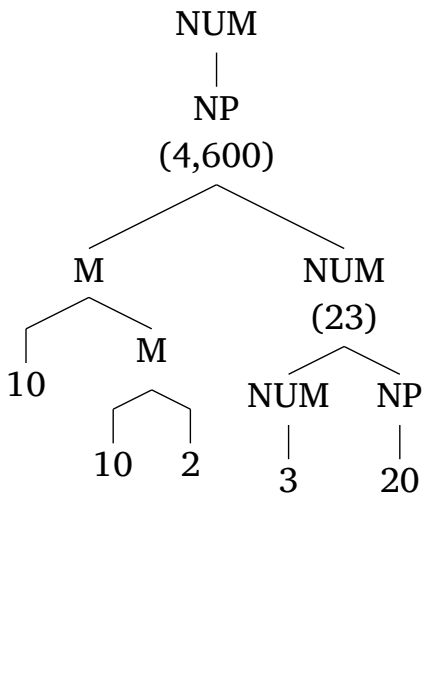

Figure 3:

Parse tree for (a) 46 derived by 4 deducted from (10 deducted from $(20 \times 3))$ (b) 4,600 derived by $200 \times(3+20)$ (c) 4,600 derived by $(2,000 \times 2)+$ $(200 \times 3)$

(c)

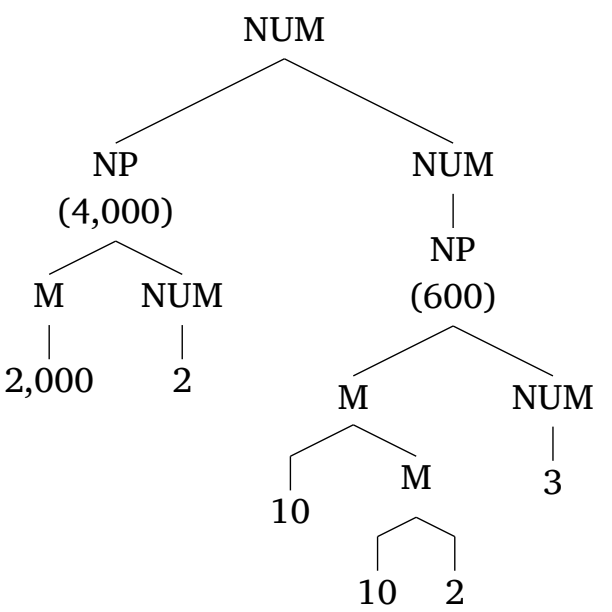




\subsection{2 Ẹkúndayọ̀'s phrase structure rules}

The study conducted by Ekkúndayọ̀ (1977) reveals that there exist similarities between the mechanism used in the Yorùbá language for constructing an infinite number of sentences from a finite set of building blocks and constructing an infinite set of numerals from a limited set of basic numbers. This proposition was corroborated into 3 different concepts as shown in Table 3. This shows that all Yorùbá numerals can be sententially represented through the addition, subtraction, and multiplication operators. The study also shows that some numbers have multiple representations in the Yorùbá language, but constraints of correctness are imposed on these representations. These constraints include linguistic and structural plausibilities.

Apart from the concept of infinity, creativity, and paraphrasable representation of numerals, Ẹkúndayọ̀ (1977) demonstrated that a recursive grammar is needed for numeral derivation and representation. It was observed that the recursive rules are not easily established for the Yorùbá numerals, however, a set of phrase structure (PS) rules for the Yorùbá numeral system was given as shown in Definition 2.

\begin{tabular}{|c|c|c|c|c|}
\hline \multirow{4}{*}{$\begin{array}{r}\text { Table 3: } \\
\text { Comparison } \\
\text { of sentence } \\
\text { construction and } \\
\text { number naming } \\
\text { in Yorùbá }\end{array}$} & No. & Concept & Language & Yorùbá numerals \\
\hline & 1 & Infinity & $\begin{array}{l}\text { There is no longest sen- } \\
\text { tence. Any sentence, } \\
\text { however long, can be ex- } \\
\text { panded. So with the use } \\
\text { of recursive rules, an infi- } \\
\text { nite number of sentences } \\
\text { can be constructed. }\end{array}$ & $\begin{array}{l}\text { Numerals are infinitely } \\
\text { enumerable. This means } \\
\text { that there is no longest } \\
\text { numeral. Any numeral, } \\
\text { however large can still be } \\
\text { increased. So, the concept } \\
\text { of recursive rules can be } \\
\text { adopted in numerals. }\end{array}$ \\
\hline & 2 & Creativity & $\begin{array}{l}\text { It is possible to construct } \\
\text { and perceive an entirely } \\
\text { new sentence that has } \\
\text { never been heard before. }\end{array}$ & $\begin{array}{l}\text { Yorùbá numerals also re- } \\
\text { quire a high level of cre- } \\
\text { ativity as higher numer- } \\
\text { als must be recreated ev- } \\
\text { ery time they are used. }\end{array}$ \\
\hline & 3 & Paraphrase & $\begin{array}{l}\text { A single idea could be } \\
\text { represented in several } \\
\text { ways. }\end{array}$ & $\begin{array}{l}\text { A single number may also } \\
\text { be represented in differ- } \\
\text { ent forms in Yorùbá nu- } \\
\text { merals. }\end{array}$ \\
\hline
\end{tabular}




\section{Definition 2 (Ẹkúndayọ̀'s PS rules for Yorùbá numerals)}

Ekúndayọ phrase structure rules for the Yorùbá numeral system are as follows:

$$
\begin{aligned}
N U M & \rightarrow \quad N P \\
N P & \rightarrow\left\{\begin{array}{l}
N P S \\
N \\
P R O N
\end{array}\right\} \\
S & \rightarrow N P \quad V P \\
V P & \rightarrow \quad V \quad N P
\end{aligned}
$$

Where NUM is a numeral and the start symbol, NP is a noun phrase, VP is a verb phrase, $S$ is a sentence, $N$ is the set of 16 basic number lexemes, $P R O N$ is the formative ó ('it'), and $V$ is a verb represented as the operating formatives ònà (for multiplication), dín (for subtraction), and lé (for addition). NOTE: Rule (8) was presented as $V \rightarrow V \quad N P$ in the original article but it was modified to make the grammar complete.

The point of interest here is that verbs are used in number naming, and that numbers are sententially represented in their surface structure. This allows for a distinction between addition and subtraction operations. This is illustrated by the structure of èrinléláàdọta (54), shown in Figure 4, where the operating formative $(V)$ is explicitly represented. Although these PS rules proved useful in the derivation of Yorùbá numerals, they are mostly arithmetic rather than syntactic rules as the positions of the basic lexical numerals and operatives do not correspond to their positions in the surface structure. An example would be the surface structure of èrinléláàdọta (54) represented in Figure 4 as ((ọgún ọnà mẹta) ó dín è̀á) ó lé ẹrin rather than ẹrin ó lé (aadín (ọgún ọnà méta)), thereby leading to a misrepresentation of numerals.

Another problem with Ẹkúndayọ̀'s PS rules is that multiplicative bases $(M)$ in Hurford's grammar are not captured. The multiplicative bases help to understand which numbers are important milestones in a numeral system. Hence, in this paper, we used knowledge from these two models to capture the essential components of the Yorùbá numerals. The grammar developed captures the multiplicative bases and treats Yorùbá numerals as both arithmetic and syntactic constructs. 


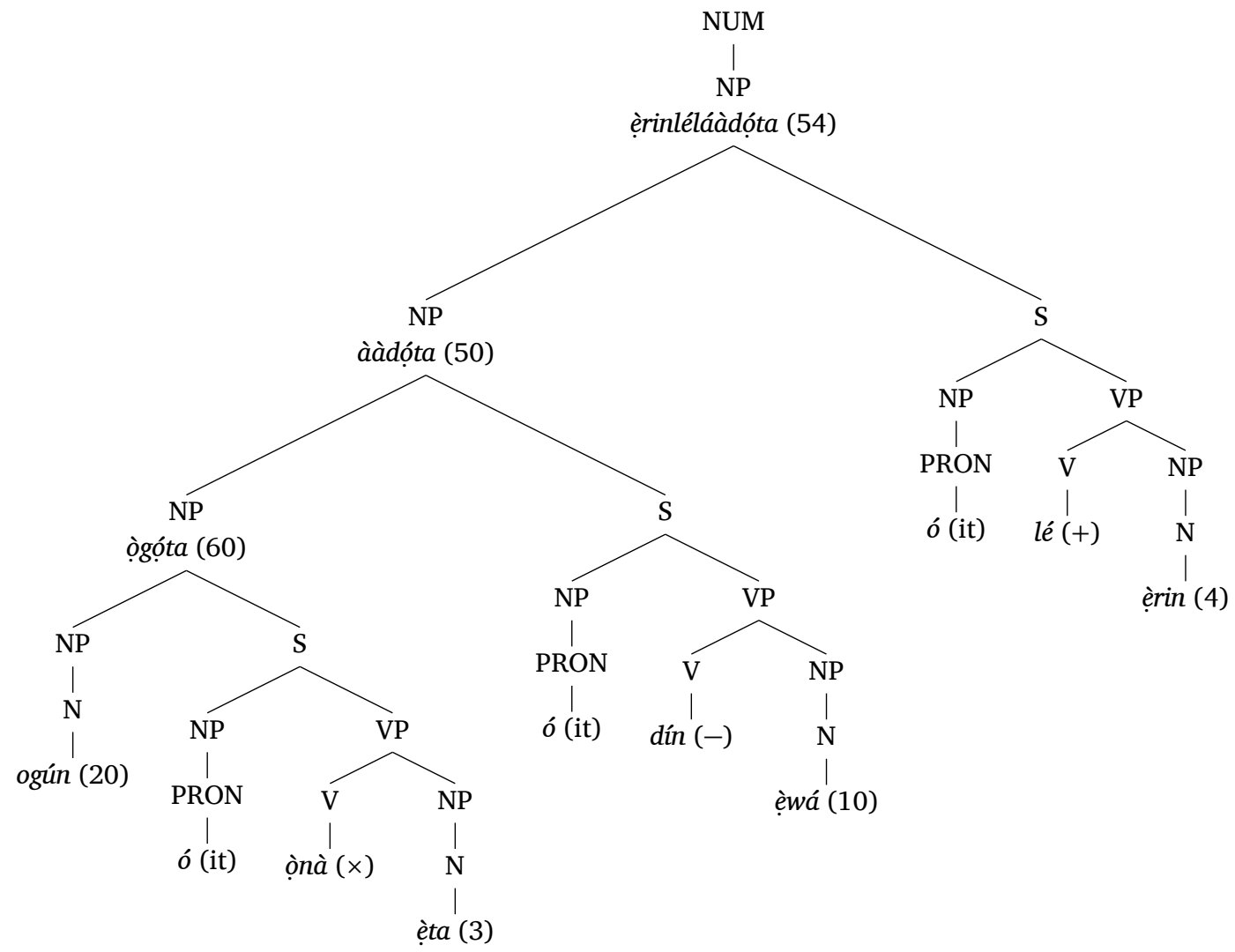

Figure 4: Parse tree for ẹrinléláàdọta (54)

It has been shown that the Yorùbá numeral system is very methodical, thus, an efficient computational system is required to gain accuracy in number representation. Figure 5 presents the block diagram of number transcription in the Yorùbá language. There are four important processes in this model. First, there is the number decomposition process, where numbers are expressed as a sum of smaller numbers in harmony with the sub-grouping discussed in Section 2.3. The output of this process is the magnitude stack. Next, there is a process that generates the possible forms of a single number. This is done by careful combinations of neighbouring elements of the magnitude stack and parsing them with the designed numeral grammar. This is done by using 


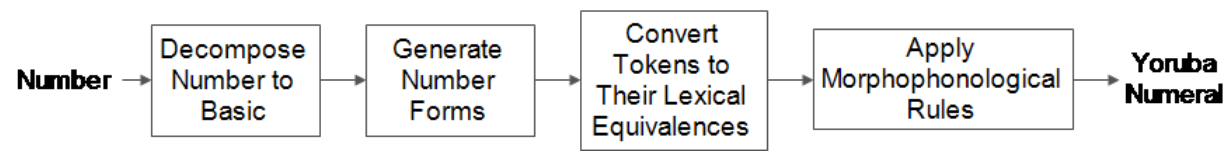

Figure 5: Number to Yorùbá text transcription system. The figure shows the processes involved in converting a cardinal number to Yorùbá text.

the packing strategy to verify whether the structures are well-formed. The third process is where tokens of the number forms are converted to their equivalent lexical forms, and the final process is where the morphophonological rules employed in Yorùbá naming numbers are applied. Number decomposition to vigesimal

Within the Yorùbá numeral system, every number can be represented using a combination of five different smaller terms, each drawn from the possible groups of the Yorùbá numeral system. So, the first process is to generate the magnitude stack from the given number. This generates five new numbers $\left(d_{0}, d_{1}, d_{2}, d_{3}, d_{4}\right)$ from the given number. So that

$$
\text { number }=d_{4}+d_{3}+d_{2}+d_{1}+d_{0}
$$

where

a) $d_{0}$ is 0 or a member of subgroup (a), i.e., $d_{0}$ takes values from 0 to 9 , i.e., $d_{0} \in$ DIGIT $=\{0,1,2, \ldots, 9\}$.

b) $d_{1}$ is 0 or a member of subgroup (b), i.e., $d_{1}$ is a multiple of $20\left(d_{1}=20 \times n \mid 0 \leq n<10\right)$ or 10 deducted from a multiple of $20\left(d_{1}=(20 \times n)-10 \mid 2 \leq n \leq 10\right)$.

c) $d_{2}$ is 0 or a member of subgroup (c), i.e., $d_{2}$ is a multiple of $200\left(d_{2}=200 \times n \mid 0 \leq n<10\right)$ or 100 deducted from a multiple of $200\left(d_{2}=(200 \times n)-100 \mid 2 \leq n \leq 10\right)$.

d) $d_{3}$ is 0 or a member of subgroup (d), i.e., $d_{3}$ is a multiple of $2,000\left(d_{3}=2,000 \times n \mid 0 \leq n<10\right)$, or 1,000 deducted from a multiple of $2,000\left(d_{3}=(2,000 \times n)-1,000 \mid 2 \leq\right.$ $n \leq 10$ ).

e) $d_{4}$ is 0 or a member of subgroup (e), i.e., $d_{4}$ is a multiple of $20,000\left(d_{4}=20000 \times n \mid 0 \leq n<\infty\right)$. 


\begin{tabular}{rll} 
Table 4: & Number & Magnitude stack \\
\cline { 2 - 3 } Magnitude stack of some numbers & 23 & {$[20,3]$} \\
& 167 & {$[160,7]$} \\
& 3,459 & {$[3,000,400,50,9]$} \\
& 19,669 & {$[19,000,600,60,9]$} \\
& 412,987 & {$[400,000,12,000,900,80,7]$} \\
& $1,876,234$ & {$[1,860,000,16,000,200,30,4]$} \\
\hline
\end{tabular}

These new numbers can be derived using Algorithm 1. Any of $d_{4}, d_{3}, d_{2}, d_{1}, d_{0}$ that is equal to zero is removed from the magnitude stack. The magnitude stacks of some numbers are presented in Table 4. For example, the magnitude stack generated for number $1,876,234$ was:

$$
\left[d_{4}, d_{3}, d_{2}, d_{1}, d_{0}\right]=[1,860,000,16,000,200,30,4]
$$

In the next section, we discuss how the representations of single numbers are generated.

Once the magnitude stack has been computed, the next task is to generate the possible forms of the number in Yorùbá. All the possible Yorùbá forms of a number are derived by some combinations of neighbouring elements of the magnitude stack. The possible forms for a number with magnitude stack of $\left[d_{4}, d_{3}, d_{2}, d_{1}, d_{0}\right]$ are listed in Table 5 . For example, the magnitude stack for 19,669 is $\left[d_{3}, d_{2}, d_{1}, d_{0}\right]=$ $[19,000,600,60,9]$, and the possible forms are shown in Table 6 . All possible forms are then stored in the form stack. However, not all numbers exhibit all these forms. The number of forms largely depends on the values of $d_{4}, d_{3}, d_{2}, d_{1}$, and $d_{0}$.

Thereafter, the elements of the form stack are expanded to a form containing only the symbols representing the basic lexical items. The expanded form stack for number 19,669 is presented in Table 7. In these forms, ' $x$ ' represents multiplication, ' - ' and ' + ' represent subtraction and addition within a number phrase respectively; '--' and '++' represent subtraction and addition between number phrases respectively, as discussed in Section $3.3 \mathrm{~b}$ (ii). It should be noted that 


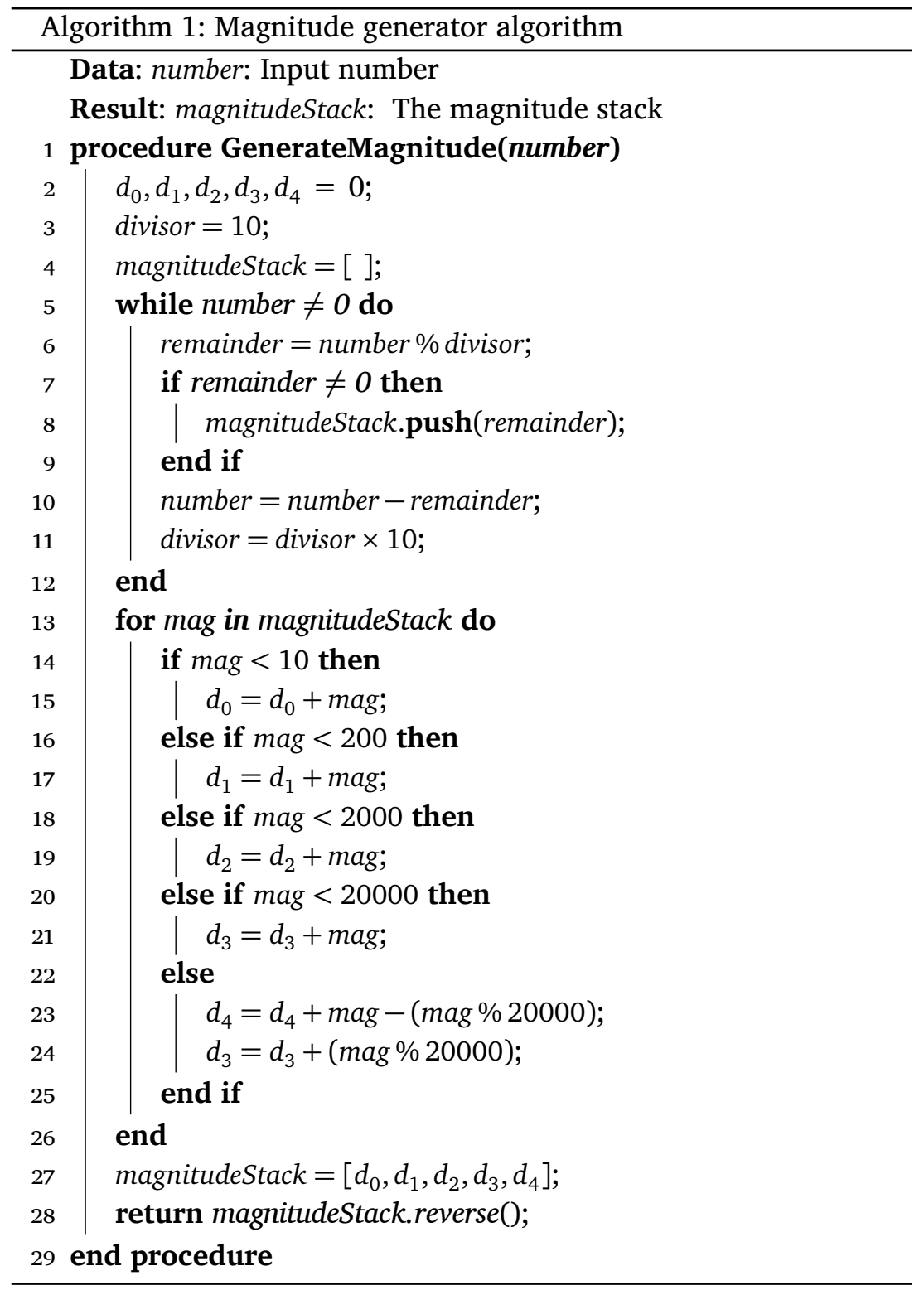

arithmetic is mostly done from right to left in the Yorùbá numeral system, i.e., $2-20$ implies 2 removed from 20 , which gives 18 . In the same way, $(10-(20 \times 4))$ implies 10 deducted from $(20 \times 4)$ to give 70 . 
Table 5:

Forms of Yorùbá number

\begin{tabular}{ll}
\hline & Derivation \\
\hline 1 & {$\left[d_{4}, d_{3}, d_{2}+d_{1}, d_{0}\right]$} \\
2 & {$\left[d_{4}, d_{3}, d_{2}+d_{1}+20, d_{0}-20\right]$} \\
3 & {$\left[d_{4}, d_{3}, d_{2}+d_{1}-20, d_{0}+20\right]$} \\
4 & {$\left[d_{4}, d_{3}, d_{2}, d_{1}+d_{0}\right]$} \\
5 & {$\left[d_{4}, d_{3}, d_{2}+100, d_{1}+d_{0}-100\right]$} \\
6 & {$\left[d_{4}, d_{3}+1000, d_{2}-1000, d_{1}+d_{0}\right]$} \\
7 & {$\left[d_{4}, d_{3}+1000, d_{2}-1000+100, d_{1}+d_{0}-100\right]$} \\
8 & {$\left[d_{4}, d_{3}+1000, d_{2}+d_{1}-1000, d_{0}\right]$} \\
9 & {$\left[d_{4}, d_{3}+d_{2}, d_{1}+d_{0}\right]$} \\
10 & {$\left[d_{4}, d_{3}+d_{2}+100, d_{1}+d_{0}-100\right]$} \\
\hline
\end{tabular}

Table 6:

Generation of the forms of 19,669 . Item $d_{4}$ is discarded because $d_{4}=0$

\begin{tabular}{lll}
\hline & Derivation & Form Stack \\
\hline 1 & {$\left[d_{3}, d_{2}+d_{1}, d_{0}\right]$} & {$[19,000,660,9]$} \\
2 & {$\left[d_{3}, d_{2}+d_{1}+20, d_{0}-20\right]$} & {$[19,000,680,-11]$} \\
3 & {$\left[d_{3}, d_{2}+d 1-20, d_{0}+20\right]$} & {$[19,000,640,29]$} \\
4 & {$\left[d_{3}, d_{2}, d_{1}+d_{0}\right]$} & {$[19,000,600,69]$} \\
5 & {$\left[d_{3}, d_{2}+100, d_{1}+d_{0}-100\right]$} & {$[19,000,700,-31]$} \\
6 & {$\left[d_{3}+1000, d_{2}-1000, d_{1}+d_{0}\right]$} & {$[20,000,-400,69]$} \\
7 & {$\left[d_{3}+1000, d_{2}-1000+100, d_{1}+d_{0}-100\right]$} & {$[20,000,-300,-31]$} \\
8 & {$\left[d_{3}+1000, d_{2}+d 1-1000, d_{0}\right]$} & {$[20,000,-340,9]$} \\
9 & {$\left[d_{3}+d_{2}, d_{1}+d_{0}\right]$} & {$[19,600,69]$} \\
10 & {$\left[d_{3}+d_{2}+100, d_{1}+d_{0}-100\right]$} & {$[19,700,-31]$} \\
\hline & &
\end{tabular}

3.3 Context-free grammar for Yorùbá numerals

We studied the structures of the five numeral groups discussed in Section 2.3, from which some patterns became apparent. We started the design of the CFG by identifying the set of terminal symbols which are:

a) The set of lexemes listed in Section 2.1.

i) DIGIT = \{ộkan (1), èjì (2), ẹta (3), ẹrrin (4), àrún-ún (5), èfà (6), èje (7), èjọ (8), èsán-án (9), ẹwá (10), ogbọ̀n (30), òdúnrún (300), irínwó (400), okòó (20), òjì (D40), ọtà (D60), ọ̀rìn (D80)\}, and

ii) The set of multiplicative bases i.e., $M=$ \{ogún (20), igba (200), ọkẹ́ $(20,000)\}$

b) The sets of lexical affixes depicting arithmetic operations in Yorùbá numerals. These three sets of operators are: 


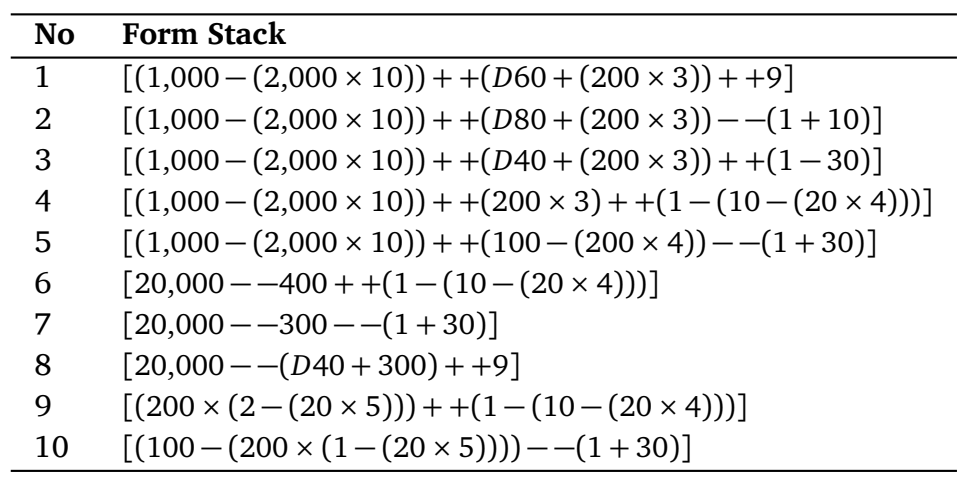

Table 7:

Expanded forms of number 19,669.

'++' and '--' are operation formatives found between phrases, while $D 40, D 60$, and $D 80$ are multiples of 20 as mentioned in Section 2.1

i) A set of operators that occur within a phrase. This includes lé ní (+) for addition and dín ní (-) for subtraction. Multiplication within a phrase is implied, which means it is not explicitly represented. Hence, $V=\{l e ́$ ní, dín ní $\}$.

ii) A set of operators that occur between phrases. This includes $o$ ó le $(++)$ for addition, ó dín (--) for subtraction and ọnà $(\times)$ for multiplication. So we say $V V=\{o ́$ lé, ó dín, ọnà $\}$.

iii) A set of implied subtraction operators represented by the prefixes aadin (reduction by 10 ) and eedin (reduction by 5,100 , and 1,000), i.e., REDUCE $=$ \{aadín, eẹdín .

Thus the set of terminal symbols, $T$, is made up of all elements in: DIGIT, $M, V, V V$, and REDUCE.

The start symbol is a numeral which is denoted by NUM. Since a CFG is the union of simpler grammars (Sipser 2007), we started by constructing rules for structures of numerals that could occur as a number phrase.

A phrase could be formed as a single DIGIT (Ekúndayọ 1977) or from the multiplication of $M$ and DIGIT. A phrase formed by multiplication is denoted by MP (Hurford 2007), i.e.,

$$
\begin{array}{lll}
N P & \rightarrow & \text { DIGIT | MP } \\
M P & \rightarrow & M \mid M P N P
\end{array}
$$

$M P$ is formed by a single multiplicative base $M$, or recursively by multiplying $M P$ by a number phrase $N P$, e.g. ogọta is formed by multiplying an $M P(20$ - formed by $M P \rightarrow M)$ and an $N P(3$ - formed 
Figure 6:

Parse tree of egbààsàn-án $(18,000)$

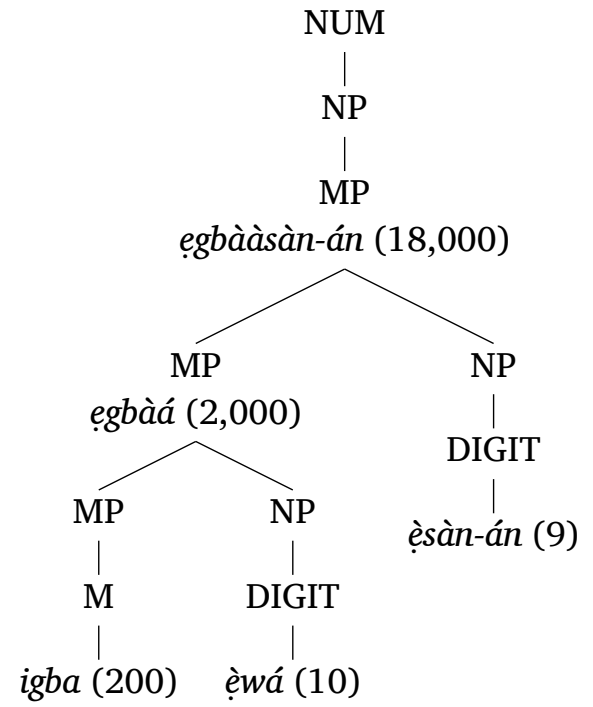

by $N P \rightarrow D I G I T)$. Also, Rule (11) is recursive to handle multiple levels of multiplication. For example, 18,000 (egbààsán) is represented as 2,000 multiplied by 9 , and 2,000 is subsequently represented as 200 multiplied by 10, as shown in the parse tree in Figure 6 .

We then added a rule to make allowance for the eedin/aadin type of subtraction. The phrase eedín/aadín can only occur as a prefix to a number derived from a multiplication operation. When this is done, the value deducted depends on the number to which it is prefixed (discussed in Subsection 2.2). A further example is 50 (ààdọta), which is derived by deducting 10 from 60 (ogọ́ta). Rule (12) captures this as shown in the structure in Figure 7.

$$
N P \rightarrow \text { REDUCE MP }
$$

With the inclusion of this rule, it should be pointed out that it has some obvious consequences. The rule overgenerates, that is, it allows the use of eedín or aadin without respecting Table 2. We shall devise means of filtering out ill-formed structures using the packing strategy.

The next stage refers to how the operators $V$ (Verbs) are represented within a phrase. Within a phrase, the Yorùbás start number presentation with the smaller number (Addend/Subtrahend) rather than the larger number (Augend/Minuend). For instance, number 21 


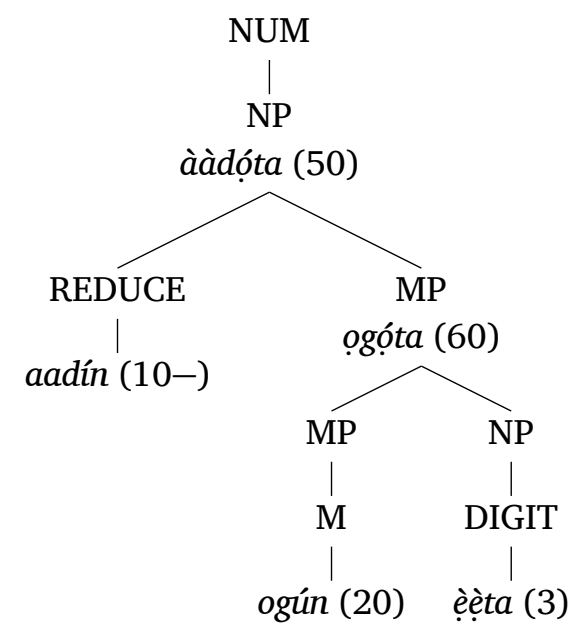

Figure 7:

Parse tree of ààdọta (50)

(twenty one) is represented as ộkànelélógún $(1+20)$ in Yorùbá. We then considered ' $1+$ ' as a verb phrase (VP), which is made up of a DIGIT and a $V$ as presented in Rule (13):

$$
V P \rightarrow \text { DIGIT } V
$$

A $V P$ can then be combined with an $N P$ to make up an $N P$, i.e.:

$$
N P \rightarrow V P N P
$$

Also, the order in Rule (11) can be reversed to capture the structure of numbers like 600,000 (ogbọ̀n ọkệ), which is represented as 30 times 20,000. The multiplicative base now is positioned at the end of the rule, and can only take ọkẹ $(20,000)$ as a value. The outcome of this new rule is a phrase (NP), since it cannot be used as a multiplicand $(M P)$ to derive higher numerals. For example, 1,200,000 cannot be represented as ogbọn ọké ọnạ méwàa $((30 \times 20,000) \times 10)$, but as òdúnrún ọkẹ́ $(300 \times 20,000)$. So we added Rule (15). The structure of number 600,000 is shown in Figure 8.

$$
N P \rightarrow N P M
$$

Next, we created rules to connect these phrases together to form a number. So, a number could be formed from a phrase, i.e.:

$$
N U M \rightarrow N P
$$


Figure 8:

Parse tree of

ogbọ̀n ọkẹ́ $(600,000)$

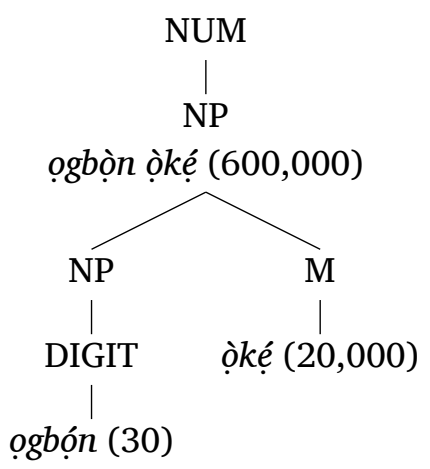

Also, a number could be formed by combining an existing number with a phrase using the lexical operatives in the set $V V$. We added two rules to capture this as follows:

$$
\begin{aligned}
\text { NUM } & \rightarrow \text { NUM } S \\
S & \rightarrow \text { VVNP }
\end{aligned}
$$

Although multiplication plays an important role in Yorùbá numerals, its lexical representation, ọnà does not occur in number names except when more than one 20,000 (ọkệ) occur within a number phrase. For example, $400,000,000$ is represented as $20,000 \times 20,000$, i.e., ọké ọnà ọké kan, and the structure is also captured using Rule (18) as shown in Figure 9.

Finally, all these rules were merged to make up the production rules of the Yorùbá numeral grammar, as presented in Definition 3.

Definition 3 (Production rules of the Yorùbá numeral grammar) The production rules for the Yorùbá numeral system are as follows:

$$
\begin{aligned}
N U M & \rightarrow \text { NP | NUM } \\
S & \rightarrow V V N P \\
N P & \rightarrow \text { DIGIT |MP |VP NP } \\
N P & \rightarrow \text { REDUCE MP |NPM } \\
M P & \rightarrow M \mid M P N P \\
V P & \rightarrow \text { DIGIT V }
\end{aligned}
$$

These phrase structure rules include the verbs which are operating formatives (V and VV) proposed by (Ẹkúndayọ 1977). These rules pro- 


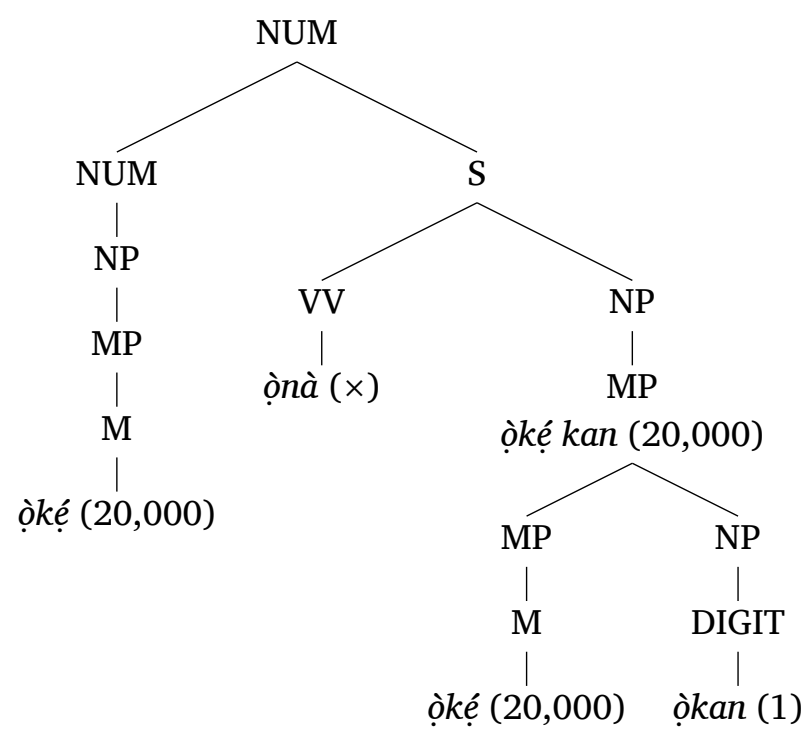

Figure 9:

Parse tree of ọkẹ ọ̀nà òkẹ kan $(400,000,000)$

duce a single and correct structure for most Yorùbá numerals, however, the rules overgenerate with some numerals. For example, the number 1,000,000 produces 3 structures as presented in Figure 10, but the valid structure is determined using a single packing strategy defined in Definition 4.

\section{Definition 4 (Packing strategy for the Yorùbá numeral system)} The following metarules govern well-formed Yorùbá numeral structures:

(i) Whenever a phrase MP is formed by a multiplicative combination of two numerals, the multiplicand (MP) must be greater than the multiplier (NP).

(ii) Whenever the rule NP $\rightarrow$ REDUCE MP is used, the lexical item of REDUCE must correspond to the appropriate MP, as shown in Table 2.

(iii) Whenever the rule $S \rightarrow V V N P$ is used and the VV has the value of ọnà, then NP can only take a value of ọkẹ, and the resulting $S$ must be used with a multiple of ọkẹ.. (see Figure 9).

Using the packing strategy for Yorùbá numerals, the well-formedness of the structures in Figure 10 was investigated and only the structure in (c) was well-formed. The analysis is as follows: 
(i) In the structure in Figure 10(b), the formation of $M P$ from ogún (20) disagrees with metarule (i), thereby making the structure in Figure 10(b) ill-formed.

(ii) The structure in Figure 10(a) is not well-formed as REDUCE (aadin $(10-)$ ) is applied to a multiple of ọkẹ $(20,000)$, which

a)

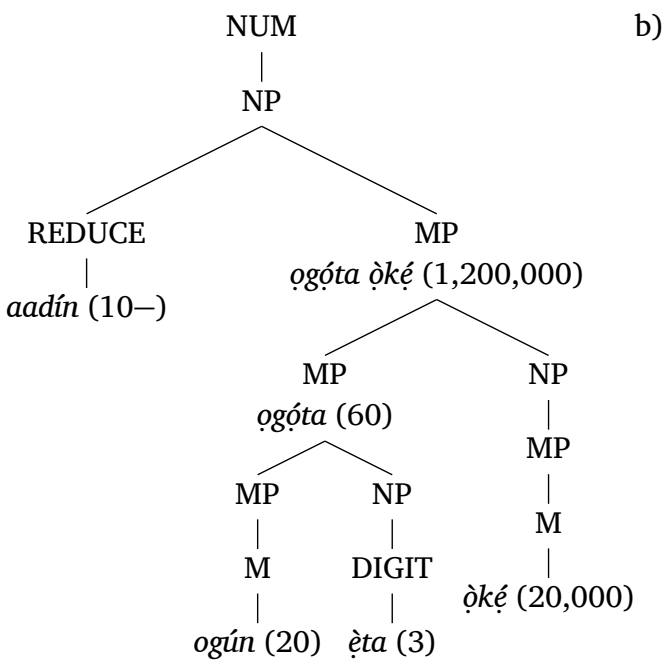

b)

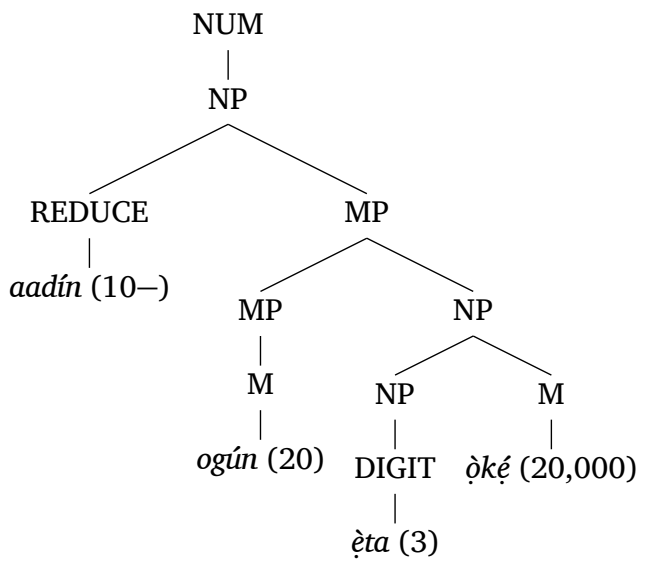

c)

NUM

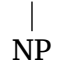

ààdọta ộké $(1,000,000)$

REDUCE
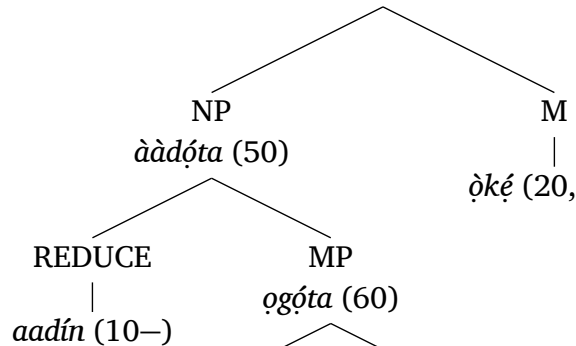

ààdọ́ta $(50)$

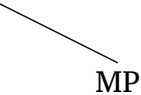

ogọta (60)

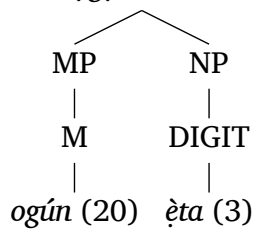

Figure 10: Parse trees of ààdọta ộkẹ $(1,000,000)$ 
disagrees with metarule (ii). Hence, only the structure in Figure $10(\mathrm{c})$ is well-formed.

Once a parse tree is generated, we then convert the tokens to their lexical equivalences followed by the application of morphophonological rules.

The representation of numbers in Yorùbá is cumbersome due to the fact that a high level of linguistic processing is involved. Therefore, the speakers are required to have adequate knowledge of some morphophonological rules in the Yorùbá language. These morphophonological rules include deletion, vowel coalescence, vowel harmony, and vowel assimilation. These rules will be discussed to show how they are useful in number naming.

Deletion

Deletion is a process by which a phrase or word is shortened by completely deleting a segment. Both vowels and consonants can be deleted in Yorùbá. The most commonly deleted consonants are $w$ (when it is part of the last syllable) and $g$. Deletion is notable in the contracted form of phrases dín ní (less than) and lé ní (more than), where $i$ is completely deleted and $n$ is converted to $l$. This conversion is possible because $n$ and $l$ are allophones of the same phoneme. For example, the expression for 28 , which is derived as 2 from 30 (èjì dín ní ogbọ̀n), is èjìdínlọgbọ̀n.

A deletion also occurs in naming numbers between 11 and 14 . For example, ókànlá (11) is formed by adding 1 to 10, i.e., òkan lé èwá, which is contracted to form òkanlẹwá by deleting the vowel é. The consonant $w$ and vowel $e$ are then deleted to form òkànlá. Another example is ẹẹdẹggệta, which is formed from eẹdín egbẹta. This is achieved by completely deleting the vowel in.

Vowel coalescence

Coalescence is a phonological process whereby two adjoining segments converge or fuse into one element such that the new segment is 
phonologically distinct from the input segments (Bámișilẹ 1994). This is illustrated by Equation 25, where $V_{1}$ is the vowel that ends the first morpheme, $V_{2}$ is the vowel that begins the second morpheme, ' + ' is the morpheme boundary, and $V_{3}$ is the resulting morpheme.

$$
V_{1}+V_{2} \rightarrow V_{3}
$$

In coalescence, the combining vowels may be phonologically distinct from each other but the resulting vowel must be distinct from the combining vowels, i.e., $V_{1} \neq V_{3}$ and $V_{2} \neq V_{3}$ (Awóbùlúyì 1987).

Vowel coalescence is most notable when two nouns are next to each other. And since Yorùbá numerals are mostly treated as nominal entities, they also use vowel coalescence in naming numbers. For example, vowel coalescence is used in the formation of ogóji (40) derived from 20 multiplied by 2, i.e., ogún èjì. The vowels ún and $e$ are combined by coalescence to become $o$. Table 8 shows the possible occurrence of vowel coalescence in the Yorùbá numeral system.

Table 8:

Vowel coalescence in Yorùbá numerals. $V_{1}$ is the vowel that ends the first morpheme, $V_{2}$ is the vowel that begins the second morpheme, + is the morpheme boundary, and $\rightarrow$ stands for 'rewritten as'

\begin{tabular}{cccl}
\hline$V_{1}$ & $V_{2}$ & $V_{3}$ & Example \\
\hline un & $a$ & $o$ & ogún + àrùn-ún $\rightarrow$ ogọ́rùn-ún \\
un & $e$ & $o$ & ogún + èjì $\rightarrow$ ogọjì \\
un & $e$ & $o$ & ogún + èta $\rightarrow$ ogọ́ta \\
$i$ & $i$ & $u$ & èjì dín ní + igba $\rightarrow$ èjìdínlúgba \\
\hline
\end{tabular}

Vowel harmony

3.4 .3

Standard Yorùbá has 7 oral vowels, which are: $a, e, e, i, o, o, u$. Vowel harmony places a constraint on the occurrence of vowel sequence in words. Archangeli and Pulleyblank (1989) discussed the two classes of Standard Yorùbá oral vowels which are:

i) Advanced Tongue Root (ATR), which are vowels $i, e, o$, and $u$,

ii) Non-ATR, which are vowels $a$, $e$, and $o$

ATR vowels involve drawing forward the root of the tongue so that the pharynx is expanded. In simple Yorùbá words, the last vowel in the word determines the other vowels in the word (Akinlabí 2004). So, if the last vowel in a word is an ATR, the immediately preceding vowel must be an ATR. The high vowels ( $i$ and $u$ ) do not participate 
in the vowel harmony at all, and they can occur with any vowel. Only the mid vowels $(e, o, e$, and $o$ ) are fully involved in the vowel harmony (Akinlabí 2004). The chart presented in Table 9 shows the permissible and non-permissible sequences of vowels in the Yorùbá language.

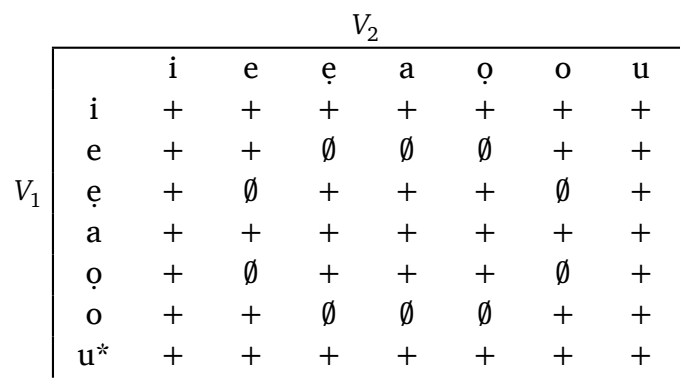

(Adapted from Archangeli and Pulleyblank (1989))

*The letter u cannot start a word in the Standard Yorùbá language.

\section{Table 9:}

Sequence of vowels in Yorùbá bisyllabic words. The symbols + and $\emptyset$ indicate the permissible and non-permissible vowel sequence, respectively. $V_{2}$ is the second oral vowel in the word and $V_{1}$ indicates the vowel that may precede $V_{2}$.

These rules also apply to number naming in Yorùbá as illustrated with the following example: The number ogọta (120) is derived as 20 (ogún) multiplied by 3 (ẹta), i.e., ogún èta. The vowels ún and è are then changed to vowel ó to form ogọta by means of vowel coalescence. Since the last vowel in the last two syllables is $a$, which is a non-ATR, therefore, the immediately preceding vowels must be non-ATR. We will then proceed to check for harmony between the first two syllables. The second vowel $o$ is non-ATR, therefore, the first vowel $o$ must also be a non-ATR. This will transform $o$ to $o$ by means of the vowel harmony.

\section{4 .4}

Vowel assimilation

Vowel assimilation is a process whereby a vowel becomes completely or partially like another vowel (Akinlabí 2004). Vowel assimilation is most notable in Yorùbá numerals when a consonant separating 2 vowels is deleted. This can be illustrated by number 2,000 (egbàá). The number 2,000 is actually formed from $200 \times 10$, i.e., igba èwá, which will produce egbẹwwá by vowel deletion. egbàá is then formed by deleting the consonant $w$ and allowing the vowel $e$ to assimilate the form of vowel $a$. 


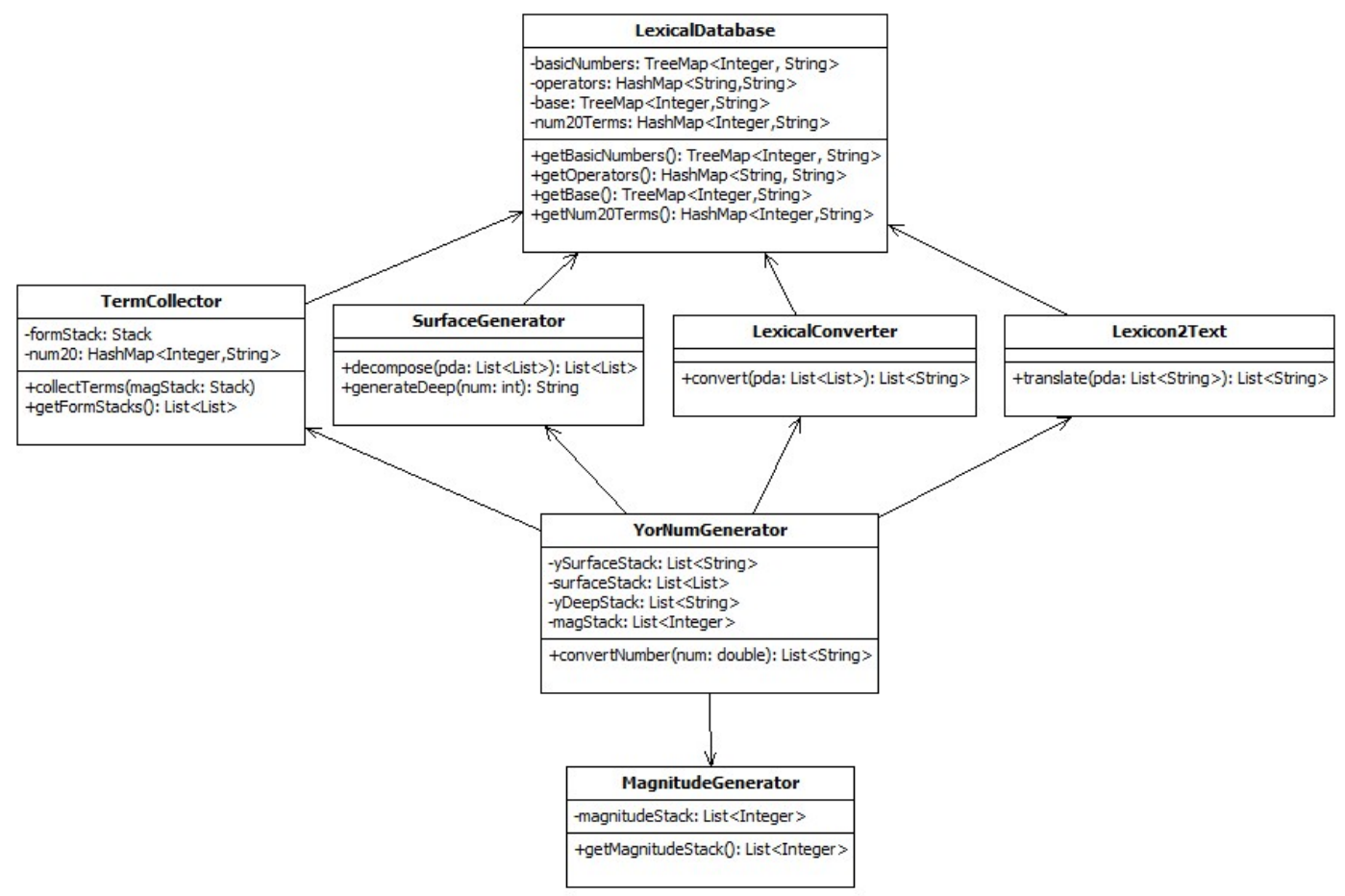

Figure 11: UML class diagram

Vowel assimilation can also occur between vowels separated by a consonant as in the expression for 800 (ẹbẹrin). This expression is derived as 200 (igba) multiplied by 4 (ẹrrin), i.e., igba ẹrrin. igbẹrrin is then formed by deleting $a$. The vowel $i$ then assimilates $e$ to form egbèrin.

An object oriented programming (OOP) approach with 7 classes was used during the system design. The UML class diagram and the sequence diagram for the software are as shown in Figure 11 and Figure 12 respectively.

The software implementation was done using Python and Java. The software was implemented following the specifications in the system design. The following software pieces were developed to demonstrate the conversion of numbers to Standard Yorùbá text: 
Numbers to Yorùbá Text

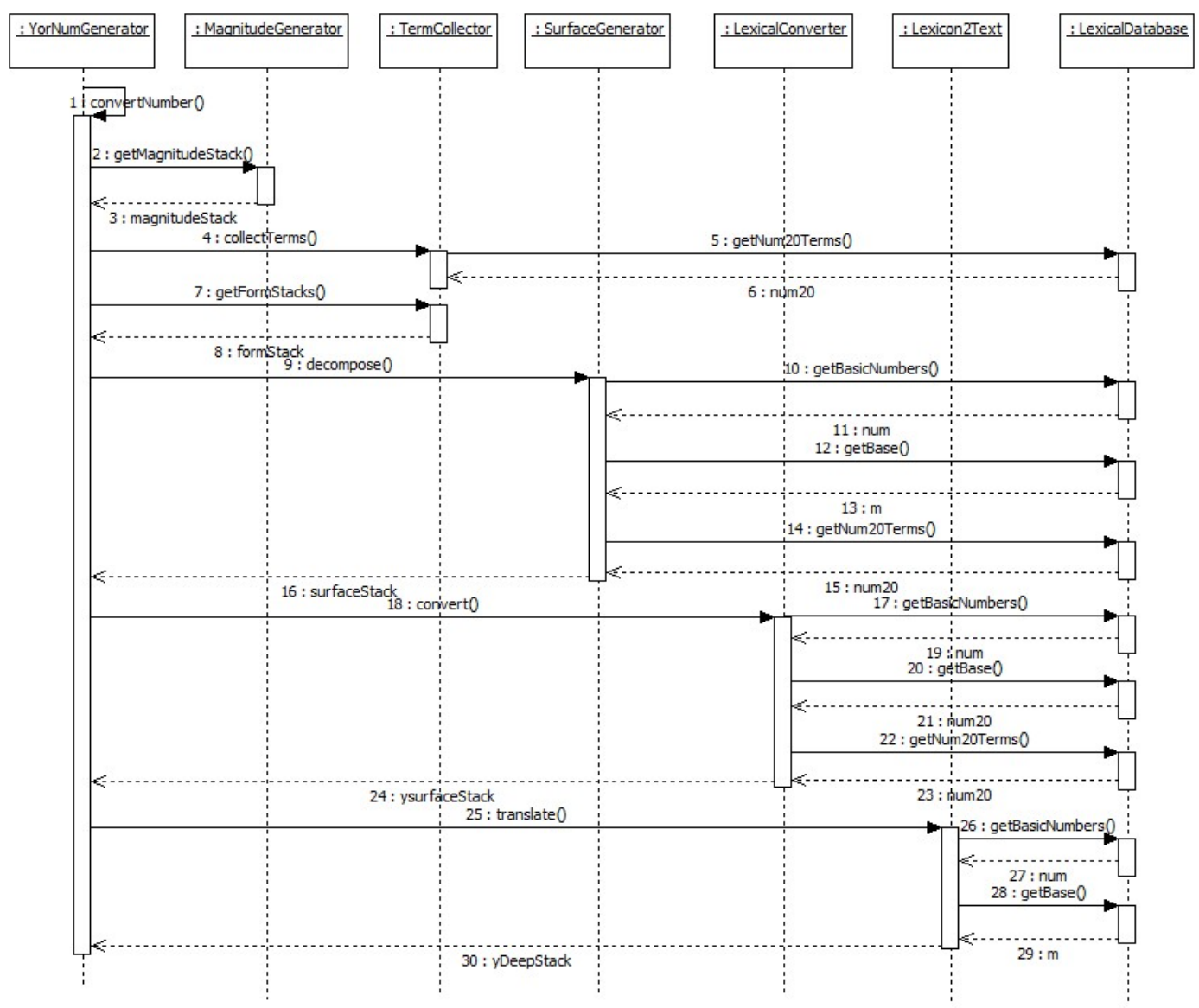

Figure 12: UML sequence diagram

a) Desktop application: The desktop application was implemented using PyQt in the Python programming language environment. The combination of Python and Qt makes possible the development of applications that are platform-independent (Summerfield 2008). NLTK (Loper and Bird 2002) was used to implement the grammar designed for the Yorùbá numeral system. It was also used to generate the parse trees of the number forms. The screenshot is as shown in Figure 13 and the software is available for download at http : //www . ifecisrg . org/yorubanumerals.

b) Web application: The web application was implemented using the Google App Engine Python API. The screenshot is as shown in 
Figure 14. The application is available at ht tp: //www. num2yor . appspot.com

c) Mobile application on Android OS: The mobile application was ported to Android using Java and the Android Application Development Toolkit (ADT). The screenshot is as shown in Figure 15.

The desktop application has a single document interface with toolbars for all tasks on top, a menu bar duplicating toolbar tasks, and a dockable history and analysis widgets. The analysis widget shows the computational details of a numeral structure. The Onka software has the following features:

a) The history can be saved for future usage.

b) Users can copy the output text to the computer's clipboard and paste it into an editing program or word processor.

c) The output of the software can be printed or saved in Unicode text format.

d) ${ }^{\mathrm{A}} \mathrm{T}_{\mathrm{E}} \mathrm{X}$ users can copy or save the output in the $\mathrm{L}_{\mathrm{E}} \mathrm{T} \mathrm{X}$ format. Also, the parse trees generated can be copied in the qtree (Siskind and Dimitriadis 2008) bracketed syntax for inclusion in $\mathrm{T}_{\mathrm{E}} \mathrm{X}$ documents.

The software produces the correct lexical transcription for numbers in the Yorùbá language. In the following subsections, analysis will be carried out on the structure, computation, and forms of certain numbers. The numbers that will be considered are $240,969,19,669$, and $40,000,000$.

The software processing of 240 produced two different forms, which are:

a. ojiléligba: This number is computed by the addition of digit 40 to 200 , i.e., [D40 + 200]. This representation uses only one addition operation. The parse tree of this representation is shown in Figure 16. This representation contains three terminal symbols, and the depth of the parse tree is 6 . 

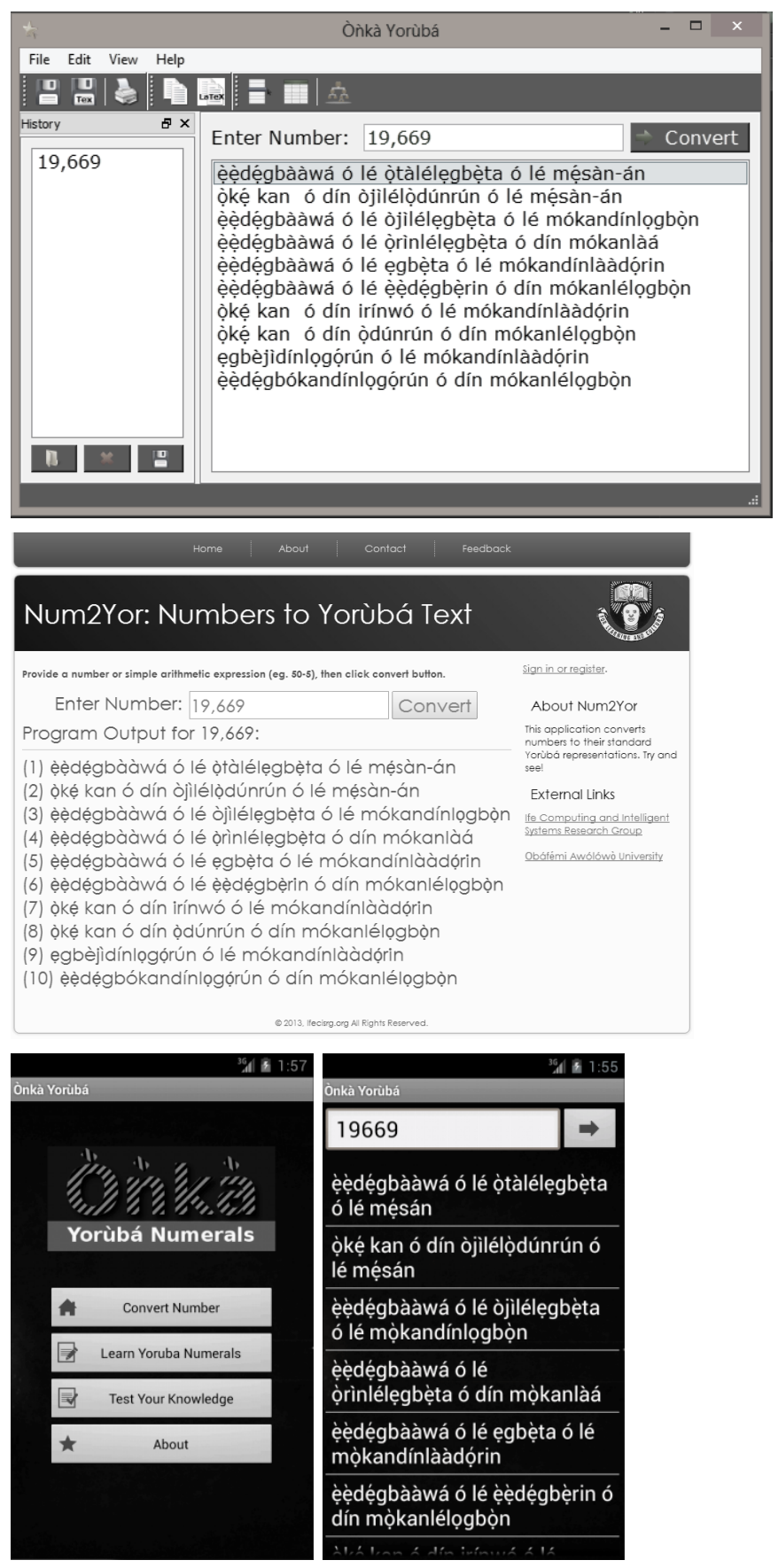

Figure 13:

Screenshot of Òǹkà desktop application

Figure 14:

Screenshot of Òǹkà web application hosted on Google App engine

Figure 15:

Screenshot of Òǹkà Android application 
Figure 16:

Parse tree of ojilélígba $(240=40$ added to 200$)$ - representation 1

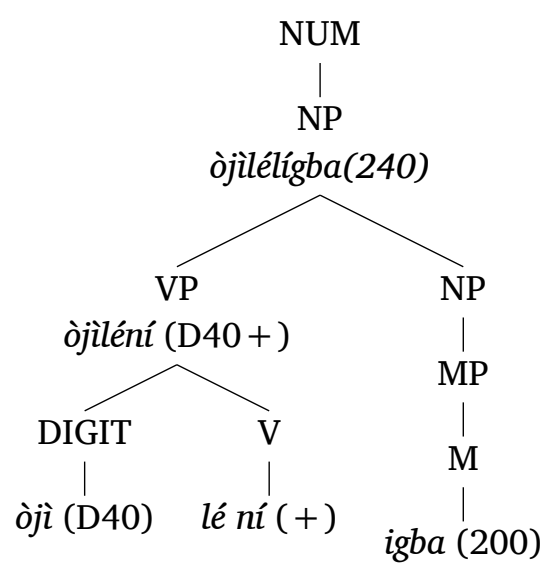

Figure 17:

Parse tree of igba ó lé ogójì $(240=200$ increased by 40$)$

- representation 2

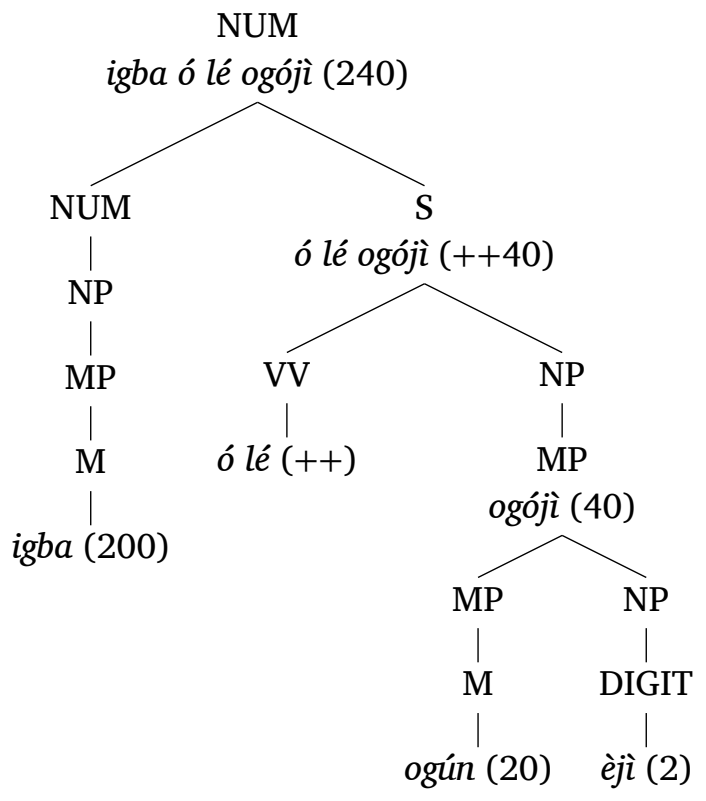

b. igba ó lé ogójì: This representation is presented as a phrase containing two number phrases. The parse tree of this representation is shown in Figure 17. This representation contains four terminal symbols, and the depth of the parse tree is 7 . 


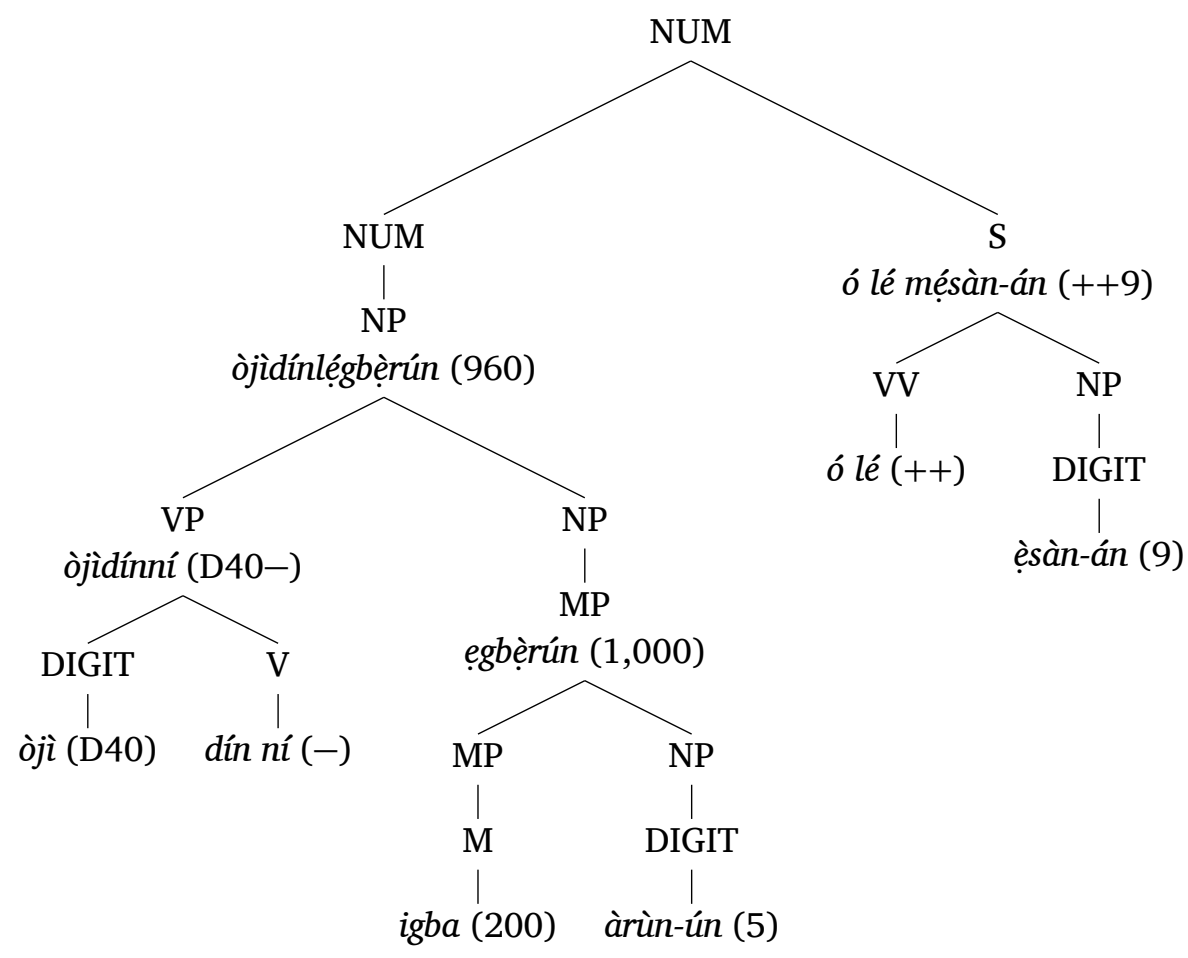

Figure 18:

Parse tree for òjìdínlegbẹrún ó lé mẹsán (969)

4.2

The number 969

The software gives 5 representations for number 969 as shown in Table 10. All these representations are valid and none has preference over others. The choice of a representation depends on the mental dexterity of the speaker. The parse tree for the first representation is shown in Figure 18.

Table 10: Representations of number 969

\begin{tabular}{cll}
\hline No & Representation & Derivation \\
\hline 1 & òjìdínlégbèrún ó lé mésàn-án & $((200 \times 5)-40)+9$ \\
2 & ọtàdínlégbẹrún ó lé mókandínlọgọ̀n & $((200 \times 5)-60)+(-1+30)$ \\
3 & okòódínlẹgbèrún ó dín mókanlàá & $((200 \times 5)-20)-11$ \\
4 & èẹ̀dẹgbẹrún ó lé mókandínlààdọ́rin & $((200 \times 5)-100)+(((20 \times 4)-10)-1)$ \\
5 & ẹbẹ̀rún ó dín mókanlélọgbọnn & $(200 \times 5)-(1+30)$ \\
\hline
\end{tabular}


Figure 19:

Parse tree of ẹbàá ộẹ́ $(40,000,000)$

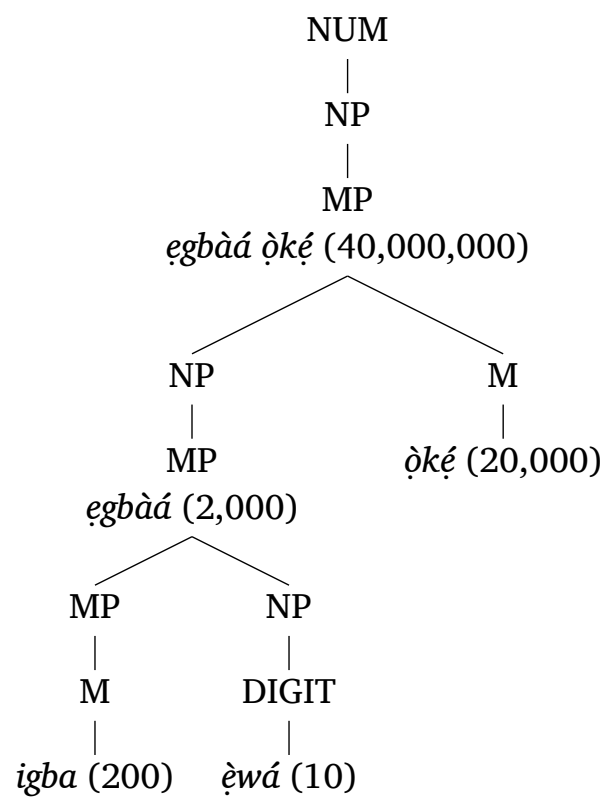

4.3

The number 19,669

The output of the software for number 19,669 is shown in Figure 14. Representations 1 to 7 were presented by Ekúndayọ (1977) and the developed software produced three more representations (8-10) that are structurally valid.

4.4

The number 40,000,000

The software gave one representation for 40,000,000 (ẹbàa ọkẹ), which is derived as a multiple of 20,000 (i.e., 2,000 $\times 20,000$ ). Next, 2,000 was derived as 200 in 10 places, i.e., $200 \times 10$. The parse tree is shown in Figure 19.

\section{SYSTEM EVALUATION}

In order to determine the accuracy of the system, we analysed and evaluated the output generated using the qualitative evaluation method. However, in these circumstances, it becomes expedient to rank the output of the software when multiple representations are produced. The aim is to order the representations according to the economy of computation. 
Although all representations produced are valid, we proposed some heuristic measures for ranking the representations when there are multiple correct expressions for a number. Once the parse tree had been generated for each representation, we computed the values to determine the computational economy of the numeral structure in the following order:

i) The total number of terminal nodes $(t)$ : This represents the number of basic lexical items that make up a Yorùbá numeral. The fewer the number of terminal nodes, the more economical the numeral structure is.

ii) The height of the parse tree $(h)$ : The height of the generated parse tree was determined by using the height() function of the package nltk.tree. The parse tree with the least height is thus considered the most suitable representation for a number.

iii) The relative number of subtractions $(r)$ : The most natural operations in most numeral systems are addition and multiplication, yet, the Yorùbá numeral system places a higher functional load on subtraction.

The value of $r$ is calculated by dividing the number of subtraction operations by the total number of arithmetic operations as shown in Equation 26. The two possible types of subtraction are the normal subtraction operation and the eedin type of subtraction.

$$
r=\frac{\text { Number of subtraction operations }}{\text { Total number of arithmetic operations }}
$$

This means that a lower $r$ implies a higher economy.

Once the first measure has been calculated and some structures have the same cost, the second measure, which checks the height of the parse tree in each structure, is used. But, if there is still a tie in values among any of the structures, the last measure (i.e., the relative number of subtraction) is used to determine the most suitable representation for a number. To illustrate this, we used these measures to decide which of the two representations for the number 240 discussed in Section 4.1 is more computationally economical. We started 
by picking the representation with the minimum number of terminals. The parse tree in Figure 16 has three terminal symbols compared to four in Figure 17. Thus, the structure in Figure 16 is more computationally economical.

Also, the analysis of the ten representations for the number 19,669 is presented in Table 11. This shows the number of terminal symbols, the depth of the parse tree, and the arithmetic complexity. The computational cost was calculated based on these criteria, and it was used to rank the representations. The representations with the lowest number of terminal symbols and least height are representations 2 and 8 (with 8 terminal symbols and height of 8 ), however, representation 2 has the lesser relative number of subtractions. Hence, representation 2 (Figure 20) is the most computationally economical. Table 12 presents the most economical representations of selected numbers derived from the software.

Table 11: Representations for the number 19,669 and their ranks. $t$ is the number of terminal symbols, $\mathbf{h}$ is the height of the parse tree as generated by the software, and $\mathbf{r}$ is the relative number of subtraction operations in the representation

\begin{tabular}{|c|c|c|c|c|c|}
\hline No & Rank & Yorùbá Text & $\mathbf{t}$ & $\mathbf{h}$ & $\mathbf{r}$ \\
\hline 2 & 1 & ọke ó dín ojillélodúnrún ó lé mẹsán-án & 8 & 8 & 0.250 \\
\hline 8 & 2 & ọke ó dín ọdúnrún ó dín mọkanlélogbọn & 8 & 8 & 0.500 \\
\hline 7 & 3 & ọke ó dín irínwó ó lé mọkandínlaadọin & 10 & 8 & 0.500 \\
\hline 10 & 4 & ẹẹégbọkandínlogơrún ó dín mọkanlélogbọn & 10 & 10 & 0.500 \\
\hline 1 & 5 & ẹedegbààwá ó lé ọtalélegbẹta ó lé mẹsán & 11 & 9 & 0.143 \\
\hline 9 & 6 & egbèjìdínlogọrún ó lé mọkandínlaadọrin & 11 & 10 & 0.429 \\
\hline 6 & 7 & eẹegbààwá ó lé eẹdegbẹrin ó dín mọanlélogbọn & 12 & 9 & 0.375 \\
\hline 3 & 8 & eẹegbààwá ó lé ójilélegbẹta ó lé mọkandínlogbọn & 13 & 9 & 0.250 \\
\hline 4 & 9 & eẹegbààwá ó lé orinélegbẹta dín mọkanlàá & 13 & 9 & 0.250 \\
\hline 5 & 10 & eẹdegbààwá ó lé egbẹta ó lé mọkandínlaadọrin & 13 & 9 & 0.333 \\
\hline
\end{tabular}

5.2

Qualitative evaluation

The Mean Opinion Score (MOS) was used for the qualitative evaluation of the system. Chosen members of the staff of Ọbáfẹmi Awólộwọ̀ University, who are Yorùbá native speakers with adequate knowledge of the Yorùbá language and its orthography, were asked to provide the textual equivalences of some numbers in Yorùbá. Afterwards, their responses were compared to the output from the software. 
NUM

ọkẹ kan ó dín òjilélọdúnrún ó lé mẹsàn-án $(19,669)$

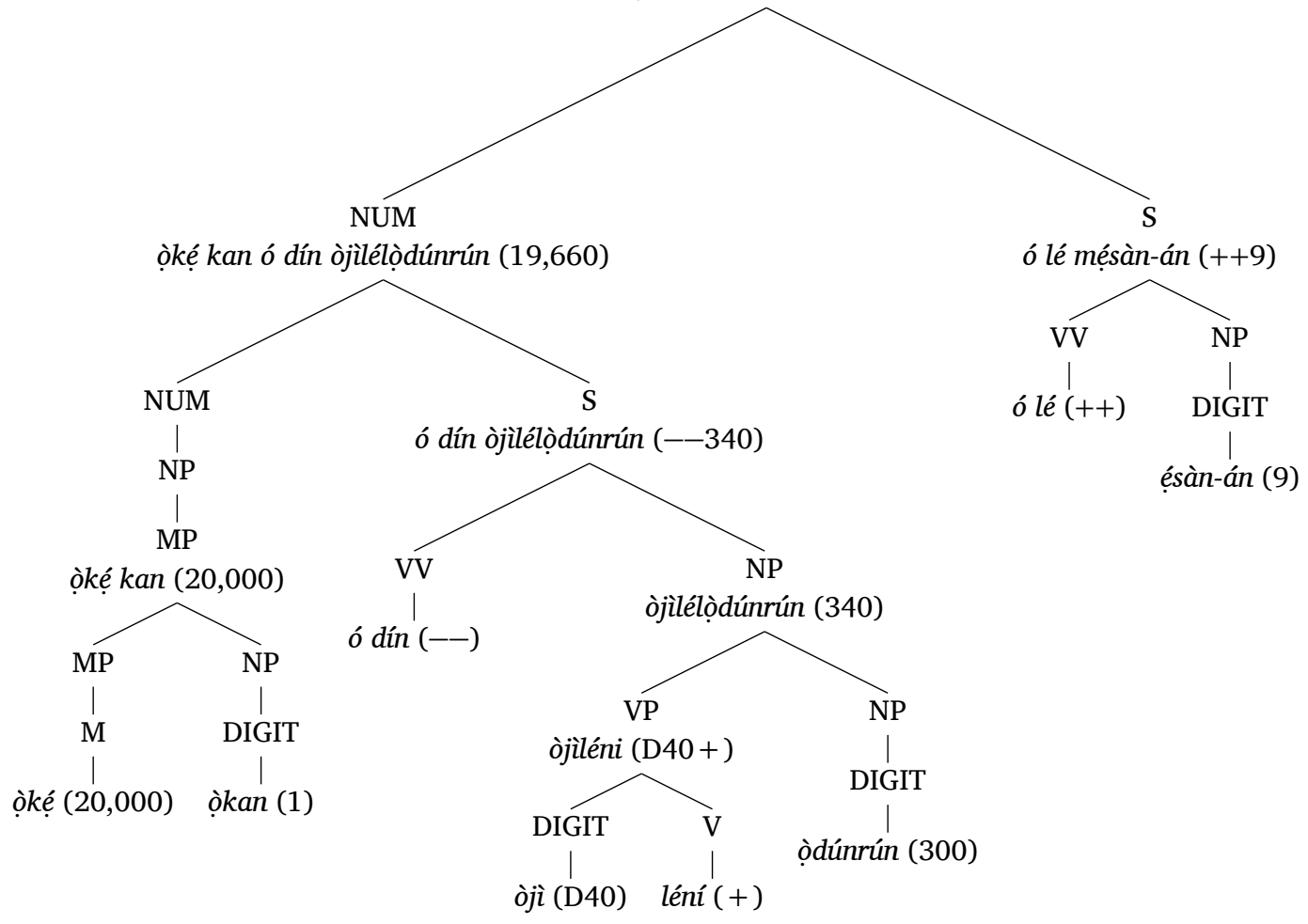

Figure 20: Parse tree for ọkệ kan ó dín òjilélọdúnrún ó lé mẹsàn-án $(19,669)$

Table 12: Software output for some numbers

\begin{tabular}{|c|c|}
\hline Number & Yorùbá Text \\
\hline 182 & ogọósán ó lé méjì \\
\hline 187 & ogọosán ó lé méje \\
\hline 365 & irinwó ó dín márùndínlógójí \\
\hline 595 & ẹbẹta ó dín márùn-ún \\
\hline 666 & ọttàlélegbẹ̀ta ó lé mẹfà \\
\hline 760 & òjìdínlégbẹrrin \\
\hline 777 & ẹẹdẹgbẹrin ó lé mẹ́tàdínlọgọorin \\
\hline 815 & ẹbẹrrin ó lé márùndínlógún \\
\hline 840 & òjìlélẹgbẹrin \\
\hline 905 & ẹẹ̀dẹgbẹrrún ó lé márùn-ún \\
\hline 1,247 & òjillélégbẹfà ó lé méje \\
\hline 600,000 & ogbọ̀n ọkẹ́ \\
\hline
\end{tabular}


A questionnaire was designed and administered to the selected group of 32 respondents. The numbers in the questionnaire were 25,67 , $132,750,969,2,400,3,000,19,669,20,000,30,000,1,000,000$, and $400,000,000$. The MOS evaluation was carried out to capture two important aspects of the Yorùbá numeral system. The first one was the ability of the respondents to give an accurate representation of the numbers in terms of value and orthography, and the second one was to obtain the most suitable representation for the numbers as provided by the respondents.

The numbers used in the questionnaires were chosen based on the following criteria:

i) Numbers 25, 67, and 132 were included to confirm that numbers between 1 and 200 have one standard lexical form.

ii) Numbers 750, 969, 2,400, and 19,669 were included to check whether the respondents are aware that there are multiple representations for these Yorùbá numerals.

iii) The number 20,000 was included to check whether the respondents find 20,000 as a single lexical item or think it is derived from the number 200 .

iv) Numbers higher than $20,000(30,000,1,000,000,400,000,000)$ were included to see if the respondents represent these numbers as multiples of 20,000 or in some other way.

v) Some structurally complex numbers (969 and 19,669) were added to see the most convenient combination of basic lexical numerals used by the respondents to derive these numbers.

The results of the analysis revealed that:

- For numbers 25, 67, and 132, all the respondents gave one correct representation, which matched up with the output from the software. This shows that numbers below 200 have one standard lexical form and that the skills needed to name these numbers are well understood.

- Ten respondents gave a representation for 19,669 but only two of them gave a correct number name (eẹdegbààwá ó lé otalélegbẹta ó lé mesán and eẹdegbààwá ó lé egbẹta ó lé mọkandínlaadọrin). The other eight respondents provided number names that do not in any way evaluate to the number 19,669 . Twenty two (22) of the 
respondents did not give any representation for number 19,669. This shows that few respondents understand that 19,669 needs to be reconstructed and only two respondents were able to carry out the required computations. This result also shows that none of the respondents realised that multiple representations exist for the number 19,669.

- Seven of the respondents gave the correct number names for 20,000, with only two respondents using ọké, and the remaining five using egbààwá. This shows that few respondents were able to represent 20,000 in Yorùbá.

- Only three respondents gave the correct names for $1,000,000$ (ààdọta ọkệ), and none of the respondents gave the correct representation for 400,000,000 (ộkẹ ọnà ọkệ). This shows thatYorùbá native speakers may find the computations underlying naming large numbers cumbersome.

From these results, we conclude that the respondents were able to produce correct representations for numbers that are frequently used (number 1 to 200), although most of them were not able to produce names for higher numbers. After comparing the responses of the human evaluators with the system output, we recognise that the software out-performed the human evaluators. This affirms that most nativespeakers know the terminologies needed for large numbers but are not familiar with the expression skills required for computing their number names. Without a doubt, modern Yorùbá speakers are losing the numeral generation skills embedded in their language. An obvious reason for this is the overwhelming use of the English numerals within the Yorùbá community.

6

GONGLUSION

In this paper, we discussed extensively the computational analysis of the Yorùbá numerals. We started by identifying the basic lexical numerals and the numeral groups. Then, we designed a CFG that was able to capture the structure of the Yorùbá numerals. Furthermore, we implemented a software for converting numbers to their textual equivalences in the Yorùbá language and generating their corresponding parse trees. 
In this study, we are able to show that:

1. The Yorùbá number system has a systematic concept underlying it and that this concept can be articulated using modern computing tools and techniques.

2. The Yorùbá numeral system is not fully vigesimal. Elements of decimal (base 10) and quinary (base 5) are used in numeral representation.

3. The system's recall is $100 \%$ with respect to the corpus used in this study. This implies that, with carefully constructed computational model, the generation of the Yorùbá numeral system can be fully automated.

4. All the forms of number names produced were valid and the most computationally suitable representation are those in which : (a) the least number of terminal nodes is used, (b) the least height of the parse tree is generated, and (c) the least relative number of subtraction operations is involved. Though these measures are computationally reasonable, an interesting study will be to verify why Yorùbá native speakers sometimes prefer to adopt more complex methods, particularly when generating numerals greater that 200 .

The results of this study can be applied in Yorùbá TTS. In any TTS system, numbers must be expanded into their textual forms before the actual speech synthesis is carried out. Thus, the system developed can serve as a sub-system of a Yorùbá TTS to handle the expansion of numbers to their textual equivalences. However, additional heuristic strategies must be employed by the TTS listeners to understand the number being spoken. Without a doubt, an increased usage of the Yorùbá numerals in communication could reduce the mental task needed for number conception.

The software developed in this study has a place in effective teaching and learning of the Yorùbá language. The software can be used in classes to teach the Yorùbá numeral system and its structure. This will allow the students to see the various forms possible for a single number and to visualise the structure (parse tree) of the numerals.

There are certain areas related to this study which we cannot explore. By pointing out these areas, we hope to focus our future study on 
them. There is a need to carry out the contextual analysis of the Yorùbá numeral systems which will establish the relationships between numerals and their surrounding words. This will ensure that the expansion of numbers is carried out based on the context (cardinal, ordinal, nominal, currency, percentage, ratio, date, time, etc.) they represent. Also, there is a need to carry out a study on how the textual forms of the Yorùbá numerals could be recognised and converted to numbers. Definitely, the results of these studies could be applied in Yorùbá MT and information retrieval.

\section{AGKNOWLEDGEMENT}

This work is supported by TETFUND Grant TETF/DESS/NRF/OAU/STI /VOL.1/B1.13.9. We would like to thank the editor and anonymous reviewers for their useful comments and suggestions to enhance the quality of the paper.

\section{REFERENGES}

Wándé ABÍmbọ́lÁ (1977), Ifa Divinity Poetry, Traditional African Literature, Nok Pub Intl, New York.

Roy Clive AbRAHAM (1958), Dictionary of Modern Yorùbá, University of London Press, London.

Akinbiyi AKINLABí (2004), Understanding Yorùbá Life and Culture, chapter The Sound System of Yorùbá, pp. 453-468, Africa World Press, Trenton, NJ 08607.

Diana ARChANGeli and Douglas Pulleyblank (1989), Yorùbá Vowel Harmony, Linguistic Inquiry, 20(2):173-218.

Ọládélé AwóBùLÚYì (1987), Towards a Typology of Coalescence, Journal of West African Languages, 17(2):5-22.

David BAILEY and Jonathan BoRWEIN (2011), The Greatest Mathematical Discovery, manuscript: Available online: http://escholarship.org/uc/item/0sp6t6h5.

Rẹ̀mí BÁMIșILẸ̀ (1994), Justification for the Survival of Vowel Coalescence as a Phonological Process in Yorùbá, African Languages and Cultures, 7(2):133-142.

Levi Leonard ConANT (1896), The Number Concept: Its Origin and Development, MacMillan, New York.

Samuel ẸKÚNDAYọ̀ (1977), Vigesimal Numeral Derivational Morphology: Yorùbá Grammatical Competence Epitomized, Anthropological Linguistics, 19(9):436-453, http://www.jstor.org/stable/30027551. 
Didier Goyvaerts (1980), Counting in Logo, Anthropological Linguistics, 22(8):pp. 317-328, ISSN 00035483, http://www.jstor.org/stable/30027492.

James HURFORD (1975), The Linguistic Theory of Numerals, Cambridge University Press, Cambridge, ISBN 9780521133685.

James HURFORD (2001), Numeral Systems, in International Encyclopedia of the Social \& Behavioral Sciences, pp. 10756-10761, Elsevier Science Ltd.

James HuRford (2007), A Performed Practice Explains a Linguistic Universal: Counting Gives the Packing Strategy, Lingua, 117(5):773-783, doi:10.1016/j.lingua.2006.03.002, http://www.isrl.uiuc.edu/ amag/ langev/paper/hurford@6packingst rategy.html.

Samuel JoHnson (1921), The History of the Yorùbás: From the Earliest Times to the Beginning of the British Protectorate, Routledge and Kegan Paul, London, reprinted 1966.

Edward LOPER and Steven BIRD (2002), NLTK: The Natural Language Toolkit, in Proceedings of the ACLO2 Workshop on Effective tools and methodologies for teaching natural language processing and computational linguistics, volume 1 , p. 8, http://arxiv.org/abs/cs/0205028.

Paul Lovejoy and David Trotman (2003), Trans-Atlantic Dimensions of Ethnicity in the African Diaspora, Continuum: New York.

Adolphus MANN (1887), Notes on the Numeral System of the Yorùbá Nation, The Journal of the Anthropological Institute of Great Britain and Ireland, 16:59-64, available online: http://www.jstor.org/stable/2841738.

Karl MENninger (1969), Number Words and Number Symbols: A Cultural History of Numbers, MIT Press, Cambridge, translated by Paul Broneer for the revised German edition.

Ọdẹtúnjí Àjàdí ỌDẸ́JọBí (2003), Towards a Formal Specification of Some Computational Concepts in Yorùbá Thoughts, ODU: Ifẹ̀ Journal of the Institute of Cultural Studies, 8:87-110.

Kola OWOLABI (2006), Yoruba, Encyclopedia of Language \& Linguistics (Second Edition), pp. 735-738.

Thijs Pollmann and Carel JANSEN (1996), The Language User as an Arithmetician, Cognition, 59:219-237.

Geoffrey SAXE (1981), Body Parts as Numerals: A Developmental Analysis of Numeration among the Oksapmin in Papua New Guinea, Child Development, 51(1):306-316, Blackwell Publishing on behalf of the Society for Research in Child Development.

Michael SIPSER (2007), Introduction to the Theory of Computation, Thomas Course Technology, India, $2^{\text {nd }}$ edition, ISBN 81-315-0162-0. 
Jeffrey Mark Siskind and Alexis DimitriAdis (2008), Qtree, a $\operatorname{LAT}_{\mathrm{E}} \mathrm{X}$ Tree-drawing Package, Available online:

http://www.ling.upenn.edu/advice/latex/qtree/ (Accessed 19 September 2011).

Richard SproAT (1996), Multilingual Text Analysis for Text-to-Speech Synthesis, in W. WAHLSTER, editor, $12^{\text {th }}$ European Conference on Artificial Intelligence, pp. 75-80, John Wiley \& Sons, Ltd.

Mark Summerfield (2008), Rapid GUI Programming with Python and Qt, Prentice Hall, New Jersey, $1^{\text {st }}$ edition.

Helen VerRAN (2001), Science and an African Logic, University of Chicago Press, Chicago.

Claudia ZASLAVsky (1973), Africa Counts: Number and Pattern in African Cultures, Lawrence Hill Books, $3^{\text {rd }}$ edition.

This work is licensed under the Creative Commons Attribution 3.0 Unported License. http://creativecommons.org/licenses/by/3.๑/ 